Check for updates

Cite this: RSC Adv., 2019, 9, 25609

\title{
A highly sensitive and selective spectrofluorimetric method for the determination of cerium at pico- trace levels in some real, environmental, biological, soil, food and bone samples using 2-( $\alpha$-pyridyl)- thioquinaldinamide
}

\begin{abstract}
M. Jamaluddin Ahmed, (D)* M. Tazul Islam and Fahima Farhana
A very simple, ultra-sensitive and highly selective non-extractive new spectrofluorimetric method is presented for the determination of cerium at pico-trace levels using 2 -( $\alpha$-pyridyl)-thioquinaldinamide (PTQA). PTQA has been proposed as a new analytical reagent for the direct non-extractive spectrofluorimetric determination of cerium(Iv). This novel fluorimetric reagent, PTQA becomes oxidized in a slightly acidic $\left(0.0005-0.0015 \mathrm{M} \mathrm{H}_{2} \mathrm{SO}_{4}\right)$ solution with cerium(IV) in absolute ethanol to produce a highly fluorescent oxidized product $\left(\lambda_{\mathrm{ex}}=303 \mathrm{~nm} ; \lambda_{\mathrm{em}}=370 \mathrm{~nm}\right)$. Constant and maximum fluorescence intensities were observed over a wide range of acidity $\left(0.0005-0.0015 \mathrm{M} \mathrm{H}_{2} \mathrm{SO}_{4}\right)$ for the period between $5 \mathrm{~min}$ and $24 \mathrm{~h}$. Linear calibration graphs were obtained for $0.001-600 \mu \mathrm{g} \mathrm{L}^{-1}$ of Ce, having a detection limit of $0.1 \mathrm{ng} \mathrm{L^{-1 }}$; the quantification limit of the reaction system was found to be $1 \mathrm{ng} \mathrm{L}^{-1}$ and the RSD was $0-2 \%$. A large excess of over 60 cations, anions and complexing agents (like, chloride, phosphate, azide, tartrate, oxalate, $\mathrm{SCN}^{-}$etc.) do not interfere in the determination. The developed method was successfully used in the determination of cerium in several certified reference materials (alloys, steels, noodles, ores and sediments) as well as in some environmental waters (potable and polluted), biological fluids (human blood, urine and milk), soil samples, food samples (vegetable, rice, corn and wheat), bone samples (human, cow, bull, fish, hen, goat, sheep), solutions containing both cerium(III) and cerium(IV) and complex. The results of the proposed method for assessing biological, food and vegetables samples were comparable with ICP-OES and were found to be in excellent agreement.
\end{abstract}

Received 15th April 2019

Accepted 31st July 2019

DOI: $10.1039 / c 9 r a 02850 a$

rsc.li/rsc-advances

\section{Introduction}

Cerium is one of the most fascinating elements in the periodic table $^{\mathbf{1}}$ and continues to attract a lot of attention. Among the rare Earth elements, $\mathrm{Ce}^{3+}$ is the most widely distributed in the Earth's crust. ${ }^{2-4}$ Cerium is widely used in luminescence, ${ }^{5}$ agriculture $^{6}{ }^{6}$ textiles $^{7}$ and photographic industries, catalysis, ${ }^{8}$ nuclear energy, ${ }^{9}$ metallurgy, ${ }^{10}$ microelectronics, ${ }^{11}$ therapeutic applications, ${ }^{\mathbf{1 2}}$ magnetism, glass and ceramics, ${ }^{\mathbf{1 3}}$ lighting, ${ }^{\mathbf{1 4}}$ solar cells, ${ }^{15}$ fuel cells, ${ }^{\mathbf{1 6}}$ abrasives for chemical mechanical planarization, ${ }^{17}$ and as one of the active components of catalytic converters $^{\mathbf{1 8}}$ in vehicles. Cerium is especially interesting because of its variable electronic structure, ${ }^{19}$ which gives rise to dual valency states. Cerium is an iron-gray lustrous metal. Cerium in its tetravalent state, Ce(Iv), differs significantly from all other lanthanides due to its immense oxidizing ability in acidic solution especially in sulfuric acid solution. ${ }^{20}$ Cerium is

Laboratory of Analytical Chemistry, Department of Chemistry, University of Chittagong, Chittagong-4331, Bangladesh. E-mail: pmjahmed55@gmail.com; tazul78j@gmail.com; fahimafislam@gmail.com industrially important and is used in nuclear reactors; in alloys with nickel and chromium; and in microwave devices, lasers, and in television sets. ${ }^{20,21}$ Cerium is also used in agriculture, forestry and animal husbandry, and much attention is now being paid to the study of cerium in the environment. ${ }^{22,23}$ Addition of small amounts of the cerium to steel significantly modified its properties. ${ }^{22-24}$ Therefore, the accurate determination of cerium at trace and ultra-trace levels is important industrially.

Cerium is considered to be biologically non-essential. Cerium, like all rare Earth metals, is of low to moderate toxicity. ${ }^{25}$ Fumes from cerium fires are toxic. Workers exposed to cerium have experienced itching, sensitivity to heat and skin lesions. ${ }^{26}$ Animals injected with large doses of cerium have died due to cardiovascular collapse. Cerium can, however, replace calcium in the bone structure of the human body, which may cause skeletal problems. ${ }^{27}$ The element has also been implicated as a cause of pneumoconiosis due to inhalation of ceriumbearing dust and linked to myocardial heart disease. ${ }^{28}$ The oxalate salts of the metal have been used to remedy vomiting during pregnancy, ${ }^{29}$ while other salts of the metal have been 
used as depressants of the central nervous system, astringents, and antiseptics. The increasing industrial use of cerium and reports on cerium toxicity make it essential to have analytical procedures suitable for monitoring cerium in the environment and related fields. ${ }^{14}$ Analytically, cerium in its tetravalent state differs significantly from all other lanthanides due to its oxidizing ability in acidic solutions. ${ }^{30}$ This property of Ce(Iv) stands in the way of its determination by organic reagents. This necessitated the development of convenient and reliable analytical methods for the determination of cerium. Analytical techniques such as X-ray fluorescence, ${ }^{31}$ ICP-AES, ${ }^{32}$ electrothermal atomic absorption, ${ }^{33}$ ICP-OES, ${ }^{34}$ ICP-MS, ${ }^{35,36}$ spectrophotometry ${ }^{37-39}$ and stripping voltammetry ${ }^{40,41}$ have been used to determine cerium(III) ion. Atomic absorption spectrophotometry based method lack sensitivity, while those on flame or flameless atomization or fuel rich or fuel deficient flames have proven equally ineffective. ${ }^{42}$ Spectrofluorimetric methods ${ }^{43-68}$ were also reported for the determination of cerium. However, interference from coexist ions, especially for some rare Earth ions, $\mathrm{Fe}^{3+}$ and $\mathrm{PO}_{4}{ }^{3-}$ are always faced in the existing methods.

The goal of the present work was to develop a simpler direct spectrofluorimetric method for the pico-trace determination of cerium. In the search for a more sensitive reagent in this work a new reagent was synthesized according to the method of Porter ${ }^{69}$ and a oxidation reaction of 2 -( $\alpha$-pyridyl)-thioquinaldinamide (PTQA); with Ce(Iv) and forms an intensely fluorescent oxidized product. The method possesses distinct advantages over existing methods ${ }^{43-68}$ (Table 1) with respect to sensitivity, selectivity, range of determination, simplicity, speed, $\mathrm{pH} /$ acidity range, thermal stability, accuracy, precision and ease of operation. The method is based on the oxidative reaction of non-fluorescent PTQA in a slightly acidic (0.0005-0.0015 $\left.\mathrm{M} \mathrm{H}_{2} \mathrm{SO}_{4}\right)$ solution with $\mathrm{Ce}(\mathrm{Iv})$ in presence of ethanol to produce a highly fluorescent oxidized product, followed by a direct measurement of the fluorescence intensity in an aqueous solution at room temperature. Oxidation is very rapid and no extraction is required. With suitable masking, the reaction can be made to be highly selective and the reagent blank solutions do not show any fluorescence.

\section{Experimental section}

\section{Apparatus}

A Shimadzu (Kyoto, Japan) (Model-RF-5301PC) spectrofluorophotometer with $1 \mathrm{~cm}$ quartz cells were used and a Jenway (England, UK) (Model-3010) pH meter with combination of electrodes were used for measurements of the fluorescence intensity and $\mathrm{pH}$. The calibration and linearity of the instrument were frequently checked with standard quinine sulphate (10 $\mathrm{mg} \mathrm{L}^{-1}$ ). A PerkinElmer (Toronto, Canada) (Model: Optima 5300) Inductively Coupled Plasma-Optical Emission Spectrometer (ICP-OES), $\left[\lambda=418 \mathrm{~nm}\right.$, plasma gas flow rate $\left(\mathrm{L} \mathrm{min}^{-1}\right)=$ 15 , RF power $(\mathrm{W})=1400$, nebulizer gas flow rate $\left(\mathrm{L} \mathrm{min}^{-1}\right)=1-$ 10] was used to compare of the results. The Elemental Analyzer (Exeter Analytical Inc. Model: CE 440) equipped with supersensitive thermal conductivity detector for simultaneous determination of $\mathrm{CHN}$ was used. Infrared spectrum was recorded with a FTIR spectrophotometer, Shimadzu (Kyoto, Japan)
(Model-IR Prestige 21, Detector DTGS KBr) in the range 7500$350 \mathrm{~cm}^{-1}$ and model: JEOL 500SS, magnetic field strength: 500 MHz, solvent used: DMSO D6, standard: TMS, four channel NMR spectrometer with signal-to-noise ratio of $\sim 5000: 1$ for proton were used for characterization of the ligand.

\section{Synthesis and characterization of the reagent}

2-( $\alpha$-Pyridyl)-thioquinaldinamide (PTQA, $\mathrm{C}_{15} \mathrm{H}_{11} \mathrm{~N}_{3} \mathrm{~S}$ ) (molecular wt $=265.18$ ) was synthesized according to the method of Porter. ${ }^{69}$ The mixture containing 2-aminopyridin (purity 98\%), quinaldine (99\%) and sulphur $(97 \%)$ powder in the molar ratio of $2: 1: 1.5$ were mixed and refluxed for 6 hours in $250 \mathrm{~mL}$ round bottom flask fitted with bulb condenser under controlled temperature (140150) ${ }^{\circ} \mathrm{C}$ at $1 \mathrm{~atm}$ pressure over oil bath. The reaction mixture was kept over night. The thio-compound was filtered and crystallized using petroleum ether $(60-80){ }^{\circ} \mathrm{C}$ to give a bright yellow crystalline (needle shaped) solid. The compound recrystallized from limedistilled ethanol and was kept under vacuum $(0.1 \mathrm{~mm}$ of $\mathrm{Hg})$ for 24 hours. Yield of the product was $70 \%$. The structure of the reagent is shown in Scheme 1.

\section{Characterization of the reagent}

The reagent (PTQA) was characterized by taking the melting point, elemental analysis and an FTIR spectrum (Fig. 1) and ${ }^{1} \mathrm{H}$ NMR spectrum (Fig. 2) and thermo-gravimetric analysis. The melting point of the synthesized compound (PTQA) was $155 \pm$ $2{ }^{\circ} \mathrm{C}$ (lit. $\left.155 \pm 1{ }^{\circ} \mathrm{C}\right)^{70}$ which indicated the purity of PTQA.

The results elemental analysis $(\mathrm{C}=72.25 \%, \mathrm{~N}=13.35 \%$ and $\mathrm{H}=4.25 \%$ ) of the reagent are very in good agreement with the calculated values ( $\mathrm{C}=72.43 \%, \mathrm{~N}=13.55 \%$ and $\mathrm{H}=4.55 \%)$. The FTIR spectrum of prepared reagent (PTQA) is shown in Fig. 1. The presence of FTIR peak at $1126.43 \mathrm{~cm}^{-1}$ in Fig. 1 was due to the characteristic $\mathrm{C}=\mathrm{S}$ double bond peak $\left(v^{\mathrm{C}=\mathrm{S}}, 1050-\right.$ $\left.1200 \mathrm{~cm}^{-1}\right)^{70}$ of the reagent indicating the formation of PTQA. Both FTIR spectral and elemental analysis data indicated the formation of the reagent PTQA. The formation of the reagent also tested by ${ }^{1} \mathrm{H}$ NMR spectrum is shown in Fig. 2. The steadiness of the thermogravimetric curve obtained for about $1 \mathrm{~g}$ of the reagent at $80-90{ }^{\circ} \mathrm{C}$ indicated that the reagent did not contain any moisture.

The elemental analysis was performed by the National Center of Excellence in Analytical Chemistry, University of Sindh, Pakistan and FTIR spectra was recorded with FTIR spectrophotometer in our laboratory and ${ }^{1} \mathrm{H}$ NMR spectrum was recorded from University of Kanazawa of our prepared reagent.

\section{Synthesis of the reagent}

Live subject statement. We were not aiming to carry out detailed human studies but some samples from individuals were used in our study and as such we abided by all the necessary Guidelines and Regulations of the Ministry of Health, Govt. of Bangladesh and approved by the Ethics Committee at Chittagong University and also gave consent to carry out our research. University of Chittagong, Bangladesh is committed to the protection and safety of human subjects involved in research. 


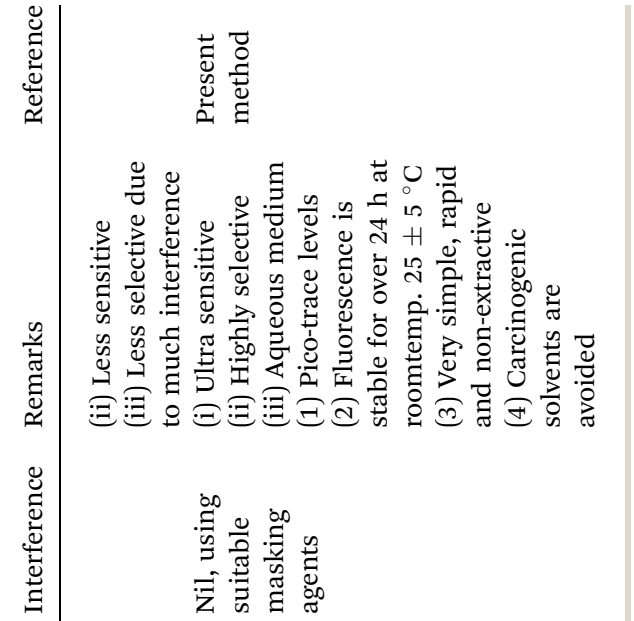

i

$\varepsilon$

के

$\stackrel{-1}{0}$

$\stackrel{8}{8}$

$\frac{1}{8}$

0
0
0
0
0
$\Sigma$
5
0
0
Reagents and solutions. All the chemicals used were of analytical reagent grade of the highest purity available. Highpurity absolute ethanol and high-purity de-ionized water were used throughout. High-purity water was obtained by passing tap water through cellulose absorbent and to mixed-bed ion exchange columns, followed by distillation in a corning AG-11 unit. Glass vessel were cleaned by soaking in acidified solutions of $\mathrm{KMnO}_{4}(98 \%)$ or $\mathrm{K}_{2} \mathrm{Cr}_{2} \mathrm{O}_{7}(99.9 \%)$ followed by washing with concentrated $\mathrm{HNO}_{3}(36 \mathrm{~N})$ and rinsed several times with high purity de-ionized water. Stock solutions and environmental water sample (1000 mL each) were kept in polypropylene bottles containing $1 \mathrm{~mL}$ concentrated $\mathrm{HNO}_{3}$. More rigorous contamination control was used when the cerium levels in the specimens were low.

PTQA solution $\left(9.8 \times 10^{-4} \mathrm{M}\right)$. The reagent solution was prepared by dissolving the requisite amount $(0.0026 \mathrm{~g})$ of PTQA, in a known volume $(10 \mathrm{~mL})$ of absolute ethanol. A freshly prepared reagent solution $\left(9.8 \times 10^{-4} \mathrm{M}\right)$ was used whenever required.

Cerium(IV) standard solution $\left(7.14 \times 10^{-3} \mathrm{M}\right)$. A $100 \mathrm{~mL}$ amount of stock solution $\left(1 \mathrm{mg} \mathrm{mL} \mathrm{mL}^{-1}\right)$ of tetravalent cerium was prepared by dissolving $288.5 \mathrm{mg}$ of ceric sulfate tetra-hydrate, $\left\{\mathrm{Ce}\left(\mathrm{SO}_{4}\right)_{2} \cdot 4 \mathrm{H}_{2} \mathrm{O}\right\}$ (Sigma-Aldrich, Merck KGaA, Germany, proanalysis grade, $99.6 \%$ ) in doubly distilled de-ionized water containing $3 \mathrm{~mL}$ of concentrated sulfuric acid and standardized by titrimetry with ethylenediaminetetraacetic acid (EDTA) using $o$-phenanthroline solution (ferroin) as indicator. ${ }^{71}$ More dilute standard solutions were prepared by appropriate dilution of aliquots from the stock solution with de-ionized water as and when required. A freshly standardized solution was always used.

Cerium(III) standard solution $\left(3.22 \times 10^{-3}\right.$ M). A $100 \mathrm{~mL}$ amount of stock solution ( $1 \mathrm{mg} \mathrm{mL}^{-1}$ ) of trivalent cerium was prepared by dissolving $309.9 \mathrm{mg}$ of cerous nitrate hexahydrate $\left\{\mathrm{Ce}\left(\mathrm{NO}_{3}\right)_{3} \cdot 6 \mathrm{H}_{2} \mathrm{O}\right\}$ (Sigma-Aldrich, Merck KGaA, pro-analysis grade, $99.5 \%$ ) in doubly distilled de-ionized water and standardized by titrimetry with ethylenediaminetetraacetic acid (EDTA) using $o$-phenanthroline solution (ferroin) as indicator. ${ }^{71}$ More dilute standard solutions were prepared by appropriate dilution of aliquots from the stock solution with de-ionized water as and when required. A freshly standardized solution was always used.

Potassium dichromate solution. A $100 \mathrm{~mL}$ amount of stock solution $(0.1 \mathrm{~N})$ was prepared by dissolving $500 \mathrm{mg}$ of finely powdered $\mathrm{K}_{2} \mathrm{Cr}_{2} \mathrm{O}_{7}$ (Merck, 99.9\%) in $100 \mathrm{~mL}$ de-ionized water.

Ammonium persuphate solution. Ammonium persuphate solution $(2 \% \mathrm{w} / \mathrm{v})$ (ACS-grade $99 \%$ pure) was freshly prepared by dissolving $2 \mathrm{~g}$ in $100 \mathrm{~mL}$ of de-ionized water.

Tartrate solution. A $100 \mathrm{~mL}$ stock solution of tartrate $(0.01 \%$ $\mathrm{w} / \mathrm{v}$ ) was prepared by dissolving $10 \mathrm{mg}$ of ACS-grade (99\%) potassium sodium tartrate tetrahydrate in $(100 \mathrm{~mL})$ de-ionized water.

Aqueous ammonia solution. A $100 \mathrm{~mL}$ solution of an aqueous ammonia solution was prepared by diluting $10 \mathrm{~mL}$ concentrated $\mathrm{NH}_{4} \mathrm{OH}(28-30 \%$, ACS-grade) to $100 \mathrm{~mL}$ with de-ionized water. The solution was stored in a polypropylene bottle. 
<smiles>Cc1ccc2ccccc2n1</smiles>

Sulphur powder<smiles>COc1ncccc1N</smiles>

Reflux at $140-150^{\circ} \mathrm{C}$

(1 atm. Pressure)<smiles>S=C(Nc1ccccc1)c1ccc2ccccc2n1</smiles>

Scheme 1 Reaction scheme of 2-( $\alpha$-pyridyl)-thioquinaldinamide (PTQA).

EDTA solution. A $100 \mathrm{~mL}$ stock solution of EDTA $(0.01 \% \mathrm{w} / \mathrm{v})$ was prepared by dissolving $10 \mathrm{mg}$ ACS-grade ( $\geq 99 \%$ ) ethylenediaminetetraacetic acid as disodium salt dehydrate in (100 $\mathrm{mL}$ ) de-ionized water.

Other solutions. Solutions of a large number of inorganic ions and complexing agents were prepared from their annular grade or equivalent grade water-soluble salts (or the oxides and carbonates in hydrochloric acid); those of niobium, tantalum, titanium, zirconium and hafnium were specially prepared from their corresponding oxides (Specpure, Johnson Matthey) according to the recommended procedures of Mukharjee. ${ }^{72}$ In the case of insoluble substances, special dissolution methods were adopted. ${ }^{73}$

\section{Procedure}

To $0.1-1.0 \mathrm{~mL}$ of a neutral aqueous solution containing $0.01-$ $6000 \mathrm{ng}$ of cerium(Iv) in a $10 \mathrm{~mL}$ calibrated flask was mixed with

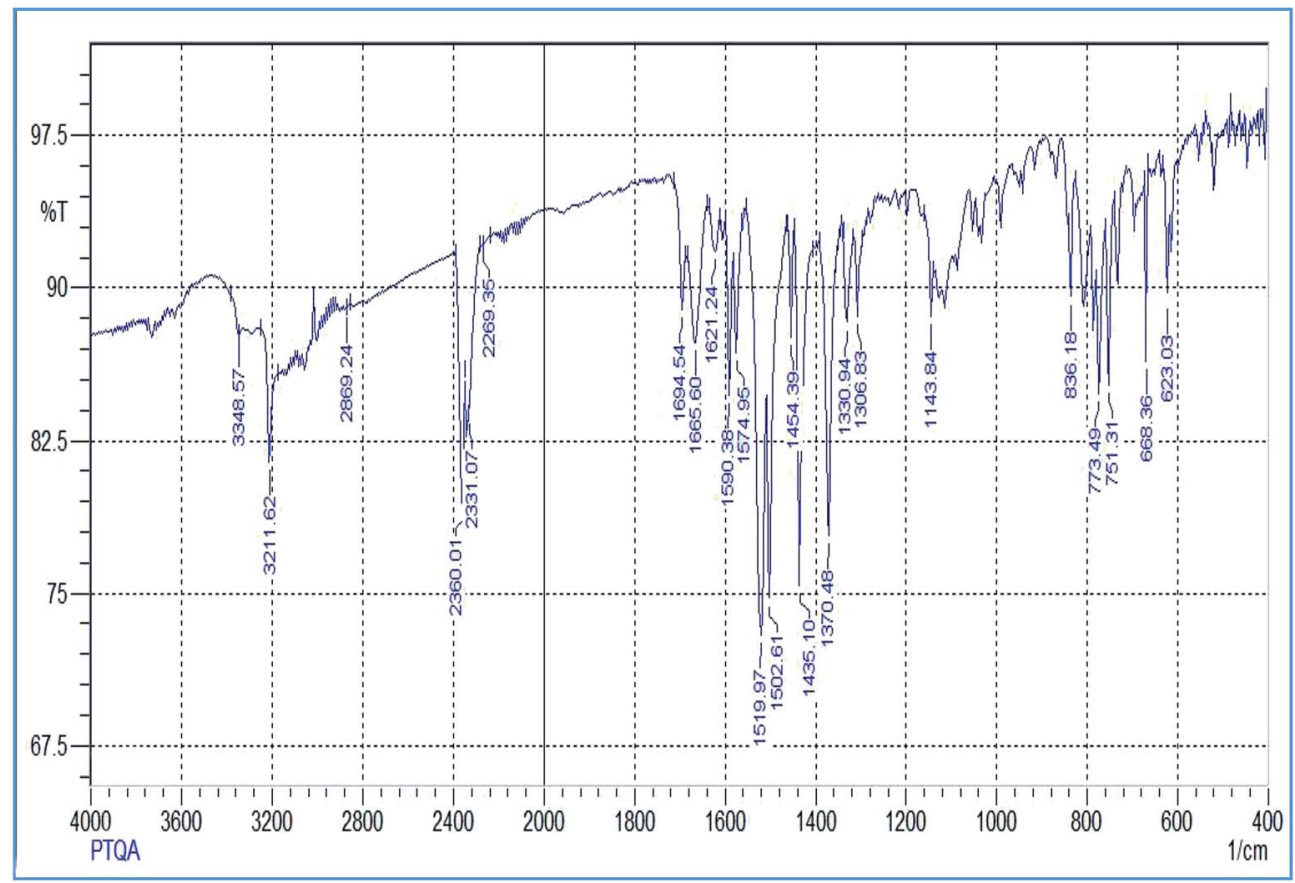

Fig. 1 FTIR spectrum of 2-( $\alpha$-pyridyl)-thioquinaldinamide. 


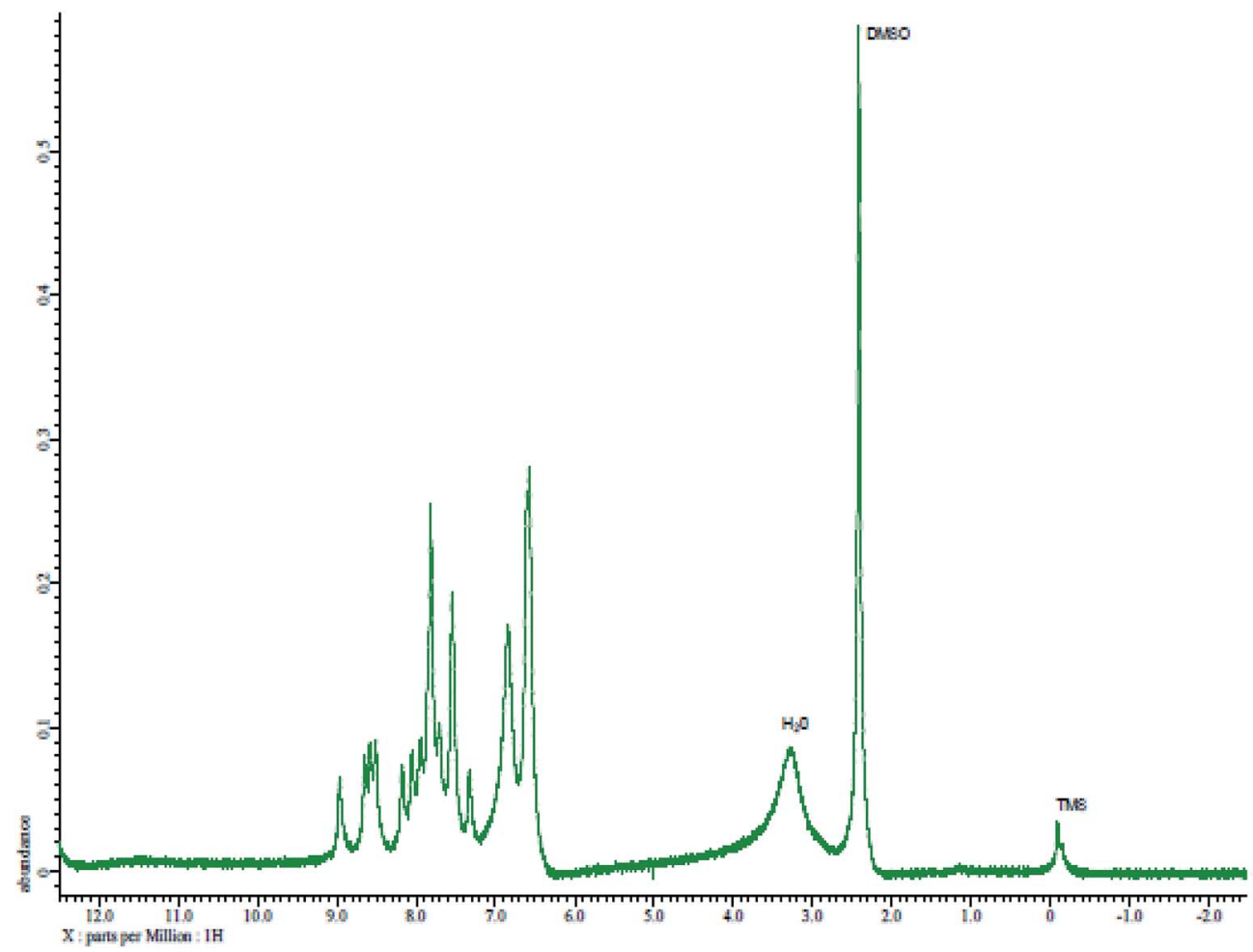

Fig. $2{ }^{1} \mathrm{H}$ NMR spectrum of 2 -( $\alpha$-pyridyl)-thioquinaldinamide (PTQA).

a $1: 250-1: 800$ fold molar excess (preferably $1 \mathrm{~mL}$ ) of $9.8 \times$ $10^{-4} \mathrm{M}$ of the 2-( $\alpha$-pyridyl)-thioquinaldinamide (PTQA) reagent solution followed by the addition of $0.5-2 \mathrm{~mL}$ (preferably $1 \mathrm{~mL}$ ) of $0.001 \mathrm{M}$ of sulfuric acid. The solution was mixed well and allowed to stand for $5 \mathrm{~min}$ after which $2 \mathrm{~mL}$ of absolute ethanol was added and the mixture was diluted to the mark with deionized water. The fluorescence intensity of the system was measured at $370 \mathrm{~nm}$ against a corresponding reagent blank, prepared concurrently, keeping the excitation wavelength maximum at $303 \mathrm{~nm}$ and the instrument setting the same. The cerium content in an unknown sample was determined using a concurrently prepared calibration graph.

\section{Sample collection and preservation}

Environmental samples. Water and soil samples were collected in polythene bottles from different places of Bangladesh. After collection, $\mathrm{HNO}_{3}\left(1 \mathrm{~mL}^{-1}\right)$ was added as preservative.

Blood, urine and milk. Blood and urine samples were collected in polythene bottles from effected persons of Chittagong Medical College Hospital, Bangladesh. Milk sample was collected from a Bangladeshi lactating mother. Immediately after collection they were stored in a salt-ice mixture and latter, at the laboratory, were at $20^{\circ} \mathrm{C}$.

Soil samples. Soil samples were collected from different locations of Bangladesh. Samples were dried in air and homogenized with a mortar.

Food samples. Food samples (rice, wheat, fruits and vegetables) were collected from local market of Chittagong. After collection the samples (fruits and vegetables) were stored in refrigerator for preservation. Samples (rice, wheat) were used as dry condition and homogenized with a mortar.
Bone samples. Bone samples of different animals were collected from local market of Chittagong, and that of human from the Chittagong Medical College Hospital. Dried samples were homogenized with a mortar. Bone samples were used as dry condition and homogenized with a mortar.

\section{Results and discussion}

\section{Factors affecting the fluorescence intensity}

Excitation and emission spectra. Ce(Iv) fluoresces strongly in PTQA solution when irradiated with ultraviolet light. The excitation and emission spectra of the fluorescent Ce(rv)-PTQA in $0.001 \mathrm{M}$ sulfuric acid medium was recorded using the spectrofluorophotometer. The excitation and emission maxima were at $303 \mathrm{~nm}$ and $370 \mathrm{~nm}$, respectively. The reagent blank exhibited negligible fluorescence, despite having wavelength maximum in the same region. In all instances, measurements were made against the reagent blank. The spectra are shown in Fig. 3.

From these spectra we performed the subsequent fluorescence measurements at $\lambda_{\mathrm{ex}}=303 \mathrm{~nm}$ and $\lambda_{\mathrm{em}}=370 \mathrm{~nm}$.

Optimization of some parameters on the fluorescence intensity

Effect of solvent. Because PTQA is insoluble in water, an organic solvent was used for the system. Of the various solvents [chloroform, benzene, carbon tetrachloride, $n$-butanol, isobutanol, ethanol, 1,4-dioxane and N,N-dimethylformamide (DMF)] were tested for the system, ethanol was found to be the best solvent for the system. The effect of ethanol on the fluorescence intensity was studied and no adverse effect was observed over a wide range of ethanol concentrations. It was 


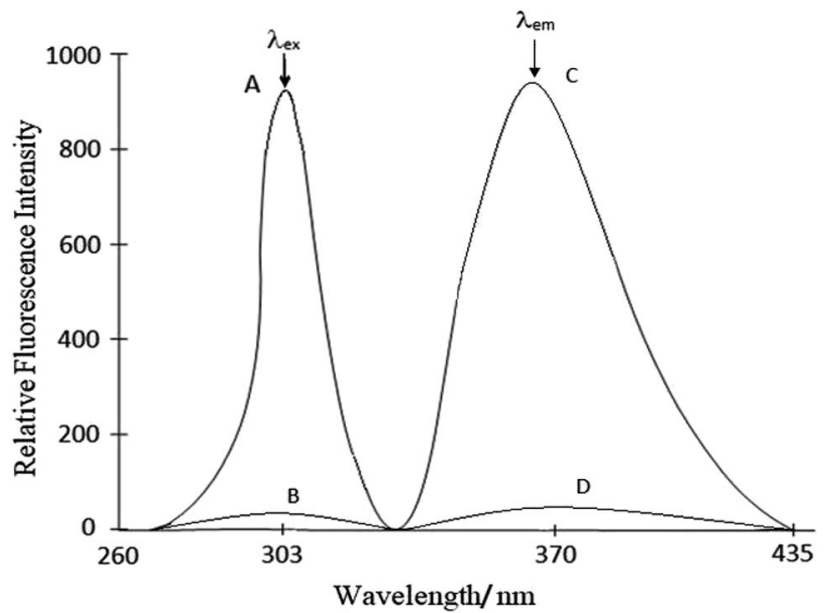

Fig. 3 Spectra $A$ and $C$ are the excitation spectra (fluorescence collected at $\lambda_{\mathrm{em}}=370 \mathrm{~nm}$ ) and emission spectra (excitation wavelength $\lambda_{\text {ex }}=303 \mathrm{~nm}$ ) of Ce $\mathrm{IV}^{\mathrm{IV}}$-PTQA system; spectra B and D are the excitation spectra (fluorescence collected at $\lambda_{\mathrm{em}}=370 \mathrm{~nm}$ ) and emission spectra (excitation wavelength $\lambda_{\mathrm{ex}}=303 \mathrm{~nm}$ ) of reagent blank, respectively in aqueous solutions.

observed that $\mathrm{Ce}^{\mathrm{IV}}$-PTQA system with $10 \mu \mathrm{g} \mathrm{L}^{-1}$ of $\mathrm{Ce}^{\mathrm{IV}}$ in absolute ethanol solution produced constant fluorescence intensity as shown in Fig. 4. A concentration of $20 \% \mathrm{v} / \mathrm{v}$ ethanol in the final volume was sufficient to prevent any precipitation or turbidity and to allow accurate measurements. Therefore, a 20\% $\mathrm{v} / \mathrm{v}$ ethanolic solution was used in the recommended procedure.

Effect of acidity or effect of $\mathrm{H}_{2} \mathrm{SO}_{4}$ concentration. The oxidation reaction was conducted in acid medium to avoid the precipitation of hydrated ceric oxide, $\mathrm{CeO}_{2} \cdot \mathrm{H}_{2} \mathrm{O}$. In order to determine the most suitable acid for the reaction, different acids (nitric, sulfuric, hydrochloric and phosphoric) were tested. But, sulfuric acid was found to be the best acid than any other mineral acids for the system. The fluorescence intensity was at maximum and constant when the $10 \mathrm{~mL}$ of solution $\left(10 \mu \mathrm{g} \mathrm{\textrm {L } ^ { - 1 }}\right.$ of $\left.\mathrm{Ce}^{\mathrm{IV}}\right)$ contained $0.5-2 \mathrm{~mL}$ of $0.0005-0.0015 \mathrm{M}$ sulfuric acid at room temperature $\left(25 \pm 5{ }^{\circ} \mathrm{C}\right)$. Outside this range of acidity, the fluorescence intensity decreased (Fig. 5). The optimum acidity range in the final solution is therefore 0.0005-0.0015 $\mathrm{M}$ (preferably $0.001 \mathrm{M}) \mathrm{H}_{2} \mathrm{SO}_{4}$. Therefore, $1 \mathrm{~mL}$ of $0.001 \mathrm{M}$ sulfuric acid solution was used for all subsequent measurements.

Effect of temperature. The influence of temperature was studied between $10-70{ }^{\circ} \mathrm{C}$. It could be observed that temperature effect is not pronounced between $10-70{ }^{\circ} \mathrm{C}$ and so room temperature $(25 \pm 5){ }^{\circ} \mathrm{C}$ is recommended for all subsequent measurements.

Effect of time. The reaction is instantaneous. The $\mathrm{Ce}^{\mathrm{IV}}-\mathrm{PTQA}$ system attained maximum and constant fluorescence intensity immediately (within $5 \mathrm{~min}$ ) after dilution of the solution to the final volume, which then remained strictly unaltered for $24 \mathrm{~h}$ at room temperature $\left(25 \pm 5{ }^{\circ} \mathrm{C}\right)$.

Effect of reagent concentration. The intensities of the fluorescence of a series of solutions containing a constant amount of $\mathrm{Ce}$ (Iv) with varying amounts of PTQA were measured in order to establish the optimum concentration of PTQA. The change of

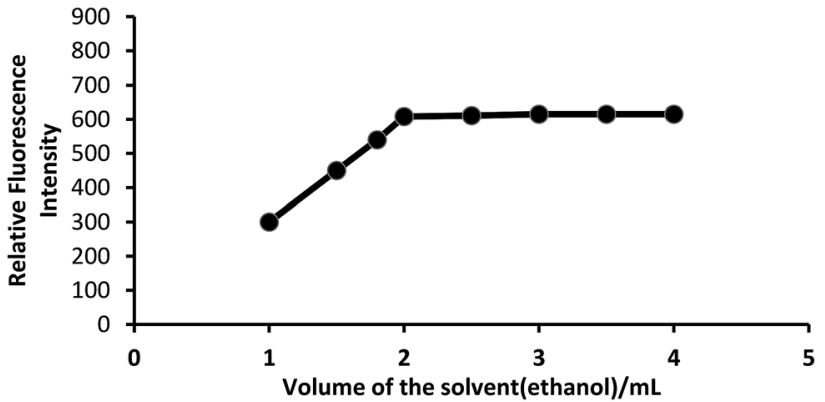

Fig. 4 Effect of solvent (ethanol) on the fluorescence of Ce $\mathrm{IV}^{\mathrm{IV}}$ PTQA system.

fluorescence intensity with PTQA concentration was shown in Fig. 6 while the concentration of $\mathrm{Ce}^{\mathrm{IV}}$ was kept constant. It was found that the fluorescence intensity increase at first as the PTQA concentration rises and reaches a maximum, but further addition of PTQA hardly effect the intensity even PTQA is more times concentrated than $\mathrm{Ce}^{\mathrm{IV}}$. It was observed that at $10 \mu \mathrm{g} \mathrm{\textrm {L } ^ { - 1 }}$ $\mathrm{Ce}^{\mathrm{IV}}$ metal and the reagent molar ratios of $1: 250$ to $1: 800$ produced a constant fluorescence intensity of the oxidized product. Outside this range of reagent, the fluorescence intensity get decreased (Fig. 6). At different $\mathrm{Ce}^{\mathrm{IV}}$ concentrations (0.5 and $1 \mu \mathrm{g} \mathrm{L}^{-1}$ ), the effect of varying the reagent concentration was similar. For all subsequent measurements $1 \mathrm{~mL}$ of $9.8 \times$ $10^{-4}$ MPTQA reagent was added.

Effect of metal concentration. The effect of Ce(Iv) solution was investigated by carrying out the reaction using $1 \mathrm{~mL}$ of $\mathrm{Ce}$ (Iv) solution of different concentrations ranging from 0.001-1000 $\mu \mathrm{g} \mathrm{L}^{-1}$. It was found that the relative fluorescence intensity increased by increasing the concentration of Ce(Iv) up to $600 \mu \mathrm{g}$ $\mathrm{L}^{-1}$, but higher concentration has negative effect on the values of the relative fluorescence intensity.

Calibration curves (Beer's law). The calibration graphs for the determination of Ce(Iv) were constructed under optimum conditions. The well-known equation for spectrofluorimetric analysis in very dilute solutions derived from Beer's law. The effect of metal concentration was studied over $0.001-1000 \mu \mathrm{g}$ $\mathrm{L}^{-1}$ distributed in six different sets $(0.001-0.01,0.01-0.1,0.1-1$,

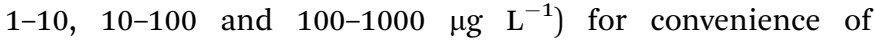
measurement. The fluorescence intensity was linear over a wide range $1 \mathrm{pg} \mathrm{mL}^{-1}$ to $600 \mu \mathrm{g} \mathrm{mL}^{-1}$ for $0.001-600 \mu \mathrm{g} \mathrm{L}^{-1}$ of cerium(Iv) at excitation wavelength at $303 \mathrm{~nm}$ and emission wavelength at $370 \mathrm{~nm}$. Of six calibration graphs, the one showing the limit of the linearity range (Fig. 7); the remaining five were straight-line graphs passing through the origin $\left(R^{2}=\right.$ 0.9998). The limit of detection and limit of quantization were found to be $0.1 \mathrm{ng} \mathrm{L}^{-1}$ and $1 \mathrm{ng} \mathrm{\textrm {L } ^ { - 1 }}$, respectively. Selected analytical parameters obtained with the optimization experiments are shown in Table 2.

Effect offoreign ions. In order to apply the proposed method to the determination of the concentration of $\mathrm{Ce}$ (Iv) in the real sample, the effect of some co-existing species was investigated using $10 \mu \mathrm{g} \mathrm{L}^{-1}$ of cerium(Iv). The tolerance limits of about 60 anions, cations and complexing agents were studied 


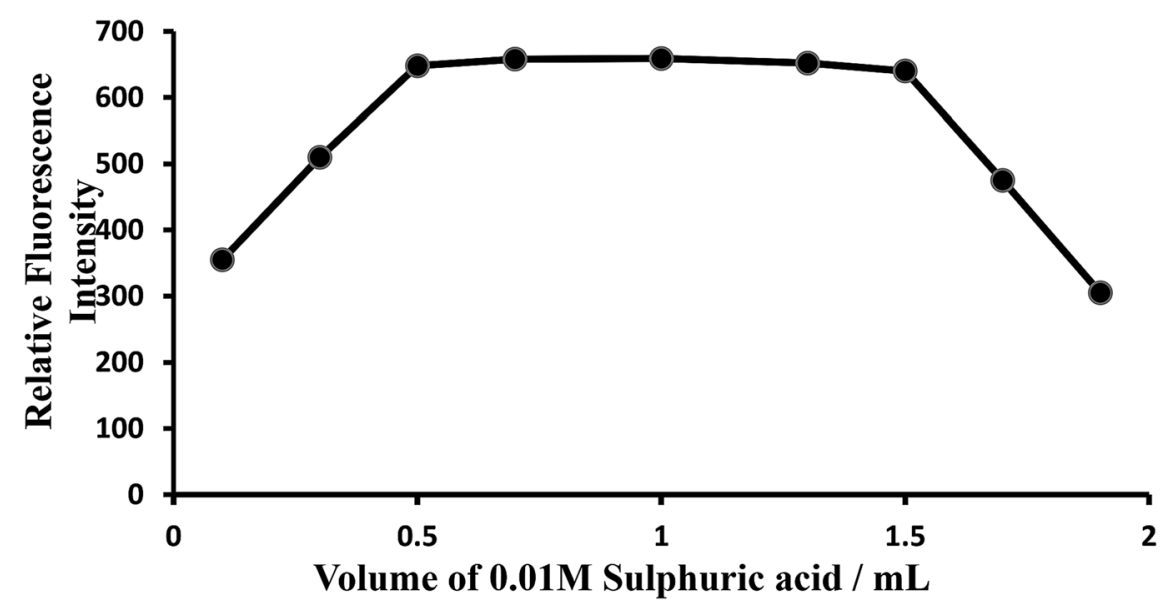

Fig. 5 Effect of acidity on the fluorescence of cerium ${ }^{\text {IV }}$-PTQA system.

individually to investigate their effect on the determination of $10 \mu \mathrm{g} \mathrm{L}^{-1}$ of cerium(Iv). The criterion for interference ${ }^{74}$ was a fluorescence intensity value varying by more than $\pm 5 \%$ from the expected value for cerium alone. The results are summarized in Table 3. As can be seen a large number of ions have no significant effect on the determination of cerium. So the method is of good selectivity.

Most of the ions were tolerated over 1000 exceeds. Ascorbic acid, oxalate, citrate, tartrate, EDTA \& fluoride ions etc. were tolerated over 5000 folds. In order to eliminate the interference of $\mathrm{Se}(\mathrm{rv}), \mathrm{Cr}(\mathrm{VI})$ and $\mathrm{Mn}$ (VII) ions, EDTA and tartrate can be used as masking agents, respectively. ${ }^{75}$ Strong reducing agents such as, tin(II), chloride, iron(II), sulfate, hydroxylamine, hydrochloride and sodium azide, which would otherwise reduce cerium(Iv), undergo oxidation during the treatment of the cerium(III) solution with persulphate and hence are not a problem. ${ }^{76}$ The amount mentioned is not the tolerance limit but the actual amount studied. However, for those ions whose tolerance limits have been studied, their tolerance ratios are mentioned in Table 3.

Precision and accuracy. The precisions of the present method were proved by measuring 10 solutions of same sample

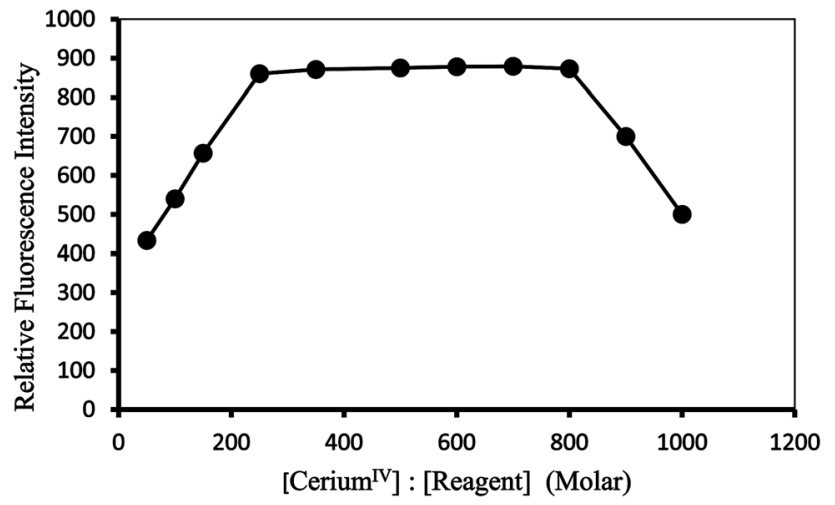

Fig. 6 Effect of reagent (PTQA: cerium ${ }^{\mathrm{IV}}$ molar concentration) on the fluorescence of cerium ${ }^{\mathrm{IV}}$-PTQA system. (each analyzed at least five times). The relative standard deviation (RSD) ( $n=5$ ) was $0-2 \%$ for $0.01-6000 \mathrm{ng}$ of cerium(Iv) in 10 $\mathrm{mL}$, indicating that this method is highly precise and reproducible (Table 2). The detection limit $(3 \times$ standard deviation (SD) of the blank) and limit of quantization (10 times of detection limit) for cerium(rv) were found to be $0.1 \mathrm{ng} \mathrm{L}^{-1}$ and $1 \mathrm{ng} \mathrm{L}^{-1}$, respectively. The method was also tested by analyzing several synthetic mixtures containing cerium(Iv) and diverse ions (Table 4). The results for total cerium were in excellent agreement with certified values (Table 5). The reliability of the procedure was tested by recovery studies. The average percentage recovery obtained for addition of cerium(Iv) spike to some environmental water samples was quantitative, as shown in Table 6. The results of biological analyses by the spectrofluorimetric method were in excellent agreement with those obtained by ICP-OES (Table 7). The results of soil analyses by the spectrofluorimetric method are shown in Table 8. The results of bone samples analyzed by the present method were found to be highly reproducible (Table 9). The results of food analyses by spectrofluorimetric method were also found to be in excellent agreement with those obtained by ICP-OES (Table 10). The results of speciation of cerium(III) and cerium(Iv) in mixtures were highly reproducible (Table 11). The statistical comparison between present and existing methods is shown in Table 12. Hence, the precision and accuracy of the method were found to be excellent.

Nature of the fluorescent species. The non fluorescent reagent, PTQA, produced the same spectral characteristics with excitation and emission wavelengths almost invariably around $303 \mathrm{~nm}$ and $370 \mathrm{~nm}$, with cerium(Iv), manganese(vII), chromium(vi), selenium(Iv) and with persulphate, hydrogen peroxide, and triiodide in acidic media. This indicates that the fluorescence species is an oxidized product of the reagent itself and not a chelate. Similar oxidative fluorescent reactions have been utilized previously. ${ }^{76,77}$ The PTQA reagent produced here has so many potential reaction sites that the structure of the oxidized fluorescent species is difficult to predict. Given that ring closure can lead to intense fluoresce in some circumstances, it seems likely that photo-oxidative cyclization takes 


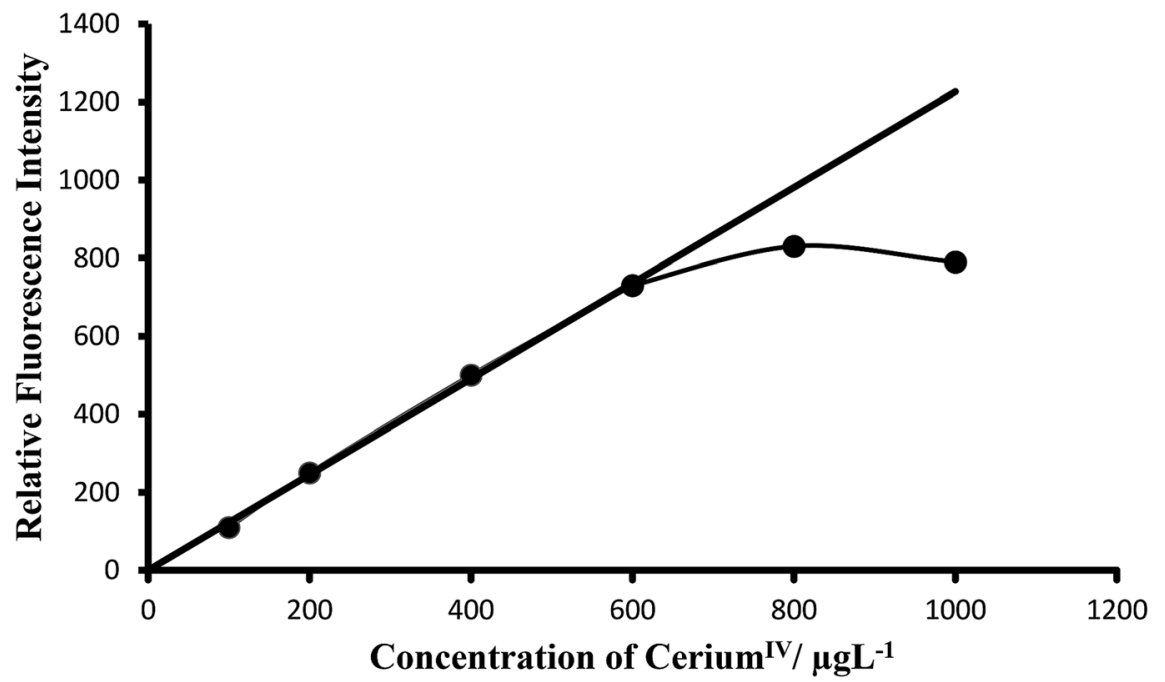

Fig. 7 Calibration graph F: $100-600 \mu \mathrm{g} \mathrm{L}^{-1}$ of cerium ${ }^{\mathrm{IV}}$. Bandwidth: Ex. slit-1.5, Em. slit-1.5. Sensitivity: high.

place, leading to the formation of structure (A) in resonance with structure (B) (Fig. 8).

\section{Applications}

The procedure was applied for determination of trace amounts of cerium in some synthetic mixtures of various compositions (Table 4) and also in a number of real samples e.g. several Certified Reference Materials (CRM) (Table 5). The method was also extended to the determination of cerium in a number of environmental, biological, soil, bone, food, vegetables and fruit samples. In view of the unknown composition of environmental water samples, the same equivalent portions of each such sample were analyzed for cerium content; the recoveries in both the "spiked" (added to the samples before the mineralization or dissolution) and the "unspiked" samples are in excellent agreement (Table 6). The results of biological analyses by spectrofluorimetric method were found to be in excellent agreement with those obtained by ICP-OES (Table 7). The results of soil analyses by the spectrofluorimetric method are shown in Table 8. The results of bone samples by the spectrofluorimetric method are shown in Table 9. The results of food analyses by spectrofluorimetric method were also found to be in excellent agreement with those obtained by ICP-OES (Table 10). The results of speciation of cerium(III) and cerium(Iv) in mixtures were highly reproducible (Table 11). The statistical comparison between proposed and reported existing methods for cerium (Table 12).

Determination of cerium in synthetic mixtures. The procedure was applied to determine trace amounts of cerium(III) in some synthetic mixtures with good recovery being achieved. The result indicate the proposed method is suitable and can be successfully applied for determination of Ce(Iv). Several synthetic mixtures of varying compositions containing cerium(Iv) and diverse ions of known concentrations were determined by the present method using EDTA as masking agent. The results were found to be highly reproducible as shown in Table 4. Accurate recoveries were achieved in all solutions in the range $99.6 \pm 1.5$ to $99.9 \pm 0.6$. The reliability of our ceriumPTQA oxidation procedure was approved by quantitative recovery of cerium(Iv) spiked in several synthetic mixtures containing cerium(Iv) and diverse ions. This method has high precision and accuracy ( $\mathrm{SD}= \pm 0.01$ for $0.5 \mu \mathrm{g} \mathrm{L}^{-1}$ ).

Table 2 Selected analytical parameters obtained with the optimization experiments

\begin{tabular}{|c|c|c|}
\hline Excitation wavelength maximum $/ \lambda_{\mathrm{ex}}(\mathrm{nm})$ & $200-700$ & 303 \\
\hline Emission wavelength maximum $/ \lambda_{\mathrm{em}}(\mathrm{nm})$ & $200-700$ & 370 \\
\hline $\mathrm{pH}$ & $2.0-7.0$ & 4.9-5.6 (preferably 5.1) \\
\hline Time/h & $0-72$ & $1 \mathrm{~min}$ to $24 \mathrm{~h}$ (preferably $5 \mathrm{~min}$ ) \\
\hline Temperature $/{ }^{\circ} \mathrm{C}$ & $5-80$ & 10-70 (preferably $25 \pm 5)$ \\
\hline Limit of quantization/ng $\mathrm{L}^{-1}$ & $0.01-100$ & 1.0 \\
\hline Detection limit/ng $\mathrm{L}^{-1}$ & $0.001-10.0$ & 0.1 \\
\hline Reproducibility (\% RSD) & $0-10$ & $0-2$ \\
\hline Regression co-efficient $\left(R^{2}\right)$ & $0.9996-0.9999$ & 0.9998 \\
\hline
\end{tabular}


Table 3 Table of tolerance limits of foreign ions ${ }^{a}$, tolerance ratio $\left[\operatorname{species}(x) / C e^{I V}(w / w)\right]$

\begin{tabular}{|c|c|c|c|}
\hline Species $\mathrm{x}$ & $\begin{array}{l}\text { Tolerance ratio } \\
\mathrm{x} / \mathrm{Ce}^{\mathrm{IV}}(\mathrm{w} / \mathrm{w})\end{array}$ & Species x & $\begin{array}{l}\text { Tolerance ratio } \\
\mathrm{x} / \mathrm{Ce}^{\mathrm{IV}}(\mathrm{w} / \mathrm{w})\end{array}$ \\
\hline Ammonium & 1000 & Lithium & 1000 \\
\hline Arsenic(III) & 1000 & Lead(II) & 1000 \\
\hline Arsenic(v) & 1000 & Magnesium & 1000 \\
\hline Aluminum & 1000 & Manganese(II) & 1000 \\
\hline Azide & 1000 & Manganese(viI) & $1000^{b}$ \\
\hline Ascorbic acid & 5000 & Mercury(II) & 1000 \\
\hline Antimony & 1000 & Molybdenum(vi) & $1000^{c}$ \\
\hline Bromide & 1000 & Nitrate & 1000 \\
\hline Bismuth(III) & 1000 & Nickel & 1000 \\
\hline Beryllium(II) & 1000 & Oxalate & 5000 \\
\hline Barium & 1000 & Potassium & 1000 \\
\hline Calcium & 1000 & Phosphate & 1000 \\
\hline Chloride & 1000 & Selenium(vi) & 1000 \\
\hline Cobalt(II) & 1000 & Selenium(Iv) & $1000^{c}$ \\
\hline Cobalt(III) & 1000 & Silver & 1000 \\
\hline Chromium(III) & 1000 & Sodium & 1000 \\
\hline Chromium(vi) & $1000^{b}$ & Strontium & 1000 \\
\hline Cadmium & 1000 & Sulfate & 1000 \\
\hline Carbonate & 1000 & Titanium(Iv) & 1000 \\
\hline Cesium & 1000 & Tellurium(Iv) & 1000 \\
\hline Citrate & 5000 & Tellurium(vi) & 1000 \\
\hline Cerium(III) & 1000 & Tartrate & 5000 \\
\hline Copper(II) & 1000 & Thiocyanate & 1000 \\
\hline Cyanide & 1000 & Thiourea & 1000 \\
\hline EDTA & 5000 & Tungsten(vi) & 1000 \\
\hline Fluoride & 5000 & $\operatorname{Tin}($ II) & 1000 \\
\hline Iodide & 1000 & $\operatorname{Tin}(\mathrm{Iv})$ & 1000 \\
\hline Iron(II) & 1000 & Vanadium(v) & 1000 \\
\hline Iron(III) & 1000 & Zinc & 1000 \\
\hline
\end{tabular}

${ }^{a}$ Tolerance limit was defined as ratio that causes less than \pm 5 percent interference. ${ }^{b}$ With $10 \mathrm{mg} \mathrm{L}^{-1}$ tartrate. ${ }^{c}$ With $10 \mathrm{mg} \mathrm{L}{ }^{-1}$ EDTA.

Determination of cerium in certified reference materials. A $0.1 \mathrm{~g}$ amount of an alloy or steel sample containing $0.465-55 \%$ of cerium was weighed accurately and placed in a $50 \mathrm{~mL}$ Erlenmeyer flask in presence of excess oxidizing agent to oxidize cerium(III) to cerium(Iv) following a method recommended by
Mitra. ${ }^{78}$ To it, $10 \mathrm{~mL}$ of $20 \%$ (w/v) sulfuric acid was added and while carefully covering with a watch glass until the brisk reaction subsided. The solution was heated and simmered gently after the addition of $10 \mathrm{~mL}$ of concentrated $\mathrm{HNO}_{3}$ until all residual carbides were decomposed. Then a further $2 \mathrm{~mL}$ of 1 $+1 \mathrm{H}_{2} \mathrm{SO}_{4}$ and $2 \mathrm{~mL} 2 \%(\mathrm{w} / \mathrm{v})$ freshly prepared persulphate were added and the solution was evaporated carefully to dense white fumes of sulphur trioxide, then cooled to room temperature (25 $\pm 5{ }^{\circ} \mathrm{C}$ ). After suitable dilution with de-ionized water, the contents of the Erlenmeyer flask were warmed so as to dissolve the soluble salts. The solution was then cooled and neutralized with dilute $\mathrm{NH}_{4} \mathrm{OH}$ in presence of $1-2 \mathrm{~mL}$ of $0.01 \%(\mathrm{w} / \mathrm{v})$ EDTA solution. The resulting solution was filtered if necessary, through a Whatman No. 40 filter paper into a $100 \mathrm{~mL}$ calibrated flask. The residue (silica and tungstenic acid) was washed with a small volume of hot $1+99 \mathrm{H}_{2} \mathrm{SO}_{4}$, followed by water; the volume was made up to mark with de-ionized water.

A suitable aliquot (1-2 mL) of the abovementioned solution was taken into a $10 \mathrm{~mL}$ calibrated flask and the cerium(Iv) content was determined; as described under procedure using tartrate or EDTA as masking agent. The proposed procedure for the spectrofluorimetric determination of cerium was applied to the analysis of single element CRM of Ce (NIST-SRM-3110), estuarine sediment (NIST-SRM-1646a), soil (SABS-SRM-19), human hair (GBW-09101), wheat flour (GBW-08503) and pine noodles (NIST-SRM-1575) CRMs obtained from The Baotou Institute of Rare Earth, Baotou, China, using tartrate or EDTA as masking agents, following a method recommended by Sun et $a .^{79}$ Based on five replicate analyses, average cerium concentration determined by the spectrofluorimetric method was in an excellent agreement with the certified values. The results are given in Table 5 .

Determination of cerium in environmental water samples. Each filtered (with Whatman No. 40) environmental sample $(25 \mathrm{~mL})$ contained in a $50 \mathrm{~mL}$ Pyrex beaker were added $1 \mathrm{~mL}$ of concentrated $\mathrm{H}_{2} \mathrm{SO}_{4}$ and $2 \mathrm{~mL}$ of concentrated $\mathrm{HNO}_{3}$ in the presence of freshly prepared excess ammonium persulphate solution in a fume cupboard to oxidize cerium(III) to

Table 4 Determination of cerium in some synthetic mixtures

\begin{tabular}{|c|c|c|c|c|}
\hline \multirow[b]{2}{*}{ Sample } & \multirow[b]{2}{*}{ Composition of mixtures $\left(\mu \mathrm{g} \mathrm{L}^{-1}\right)$} & \multicolumn{3}{|c|}{ Cerium/ $\mu g \mathrm{~L}^{-1}$} \\
\hline & & Added & Found $^{a}(n=5)$ & Recovery $\pm \mathrm{SD}^{b}(\%)$ \\
\hline \multirow[t]{2}{*}{ A } & $\mathrm{Ce}(\mathrm{Iv})$ & 1.0 & 0.99 & $99.0 \pm 0.5$ \\
\hline & & 50 & 49.98 & $99.96 \pm 0.6$ \\
\hline \multirow[t]{2}{*}{ B } & As in $\mathrm{A}+\mathrm{Cr}^{3+}(50)+\mathrm{As}^{3+}(50)+\mathrm{Co}^{2+}(50)+\mathrm{Fe}^{3+}(50)+\operatorname{EDTA}(50)$ & 1.0 & 1.0 & $100.0 \pm 0.00$ \\
\hline & & 50 & 49.98 & $99.98 \pm 0.8$ \\
\hline \multirow[t]{2}{*}{$\mathrm{C}$} & As in $\mathrm{B}+\mathrm{Pb}^{2+}(50)+\mathrm{Bi}^{3+}(50)+\mathrm{Hg}^{2+}(50)+\mathrm{Se}^{\mathrm{IV}}(50)+\mathrm{Ba}^{2+}(50)$ & 1.0 & 0.98 & $98.0 \pm 0.6$ \\
\hline & & 50 & 49.97 & $99.9 \pm 1.0$ \\
\hline \multirow[t]{2}{*}{$\mathrm{D}$} & As in $\mathrm{C}+\mathrm{Sn}^{2+}(50)+\mathrm{Cr}^{\mathrm{VI}}(50)+\mathrm{Ti}^{2+}(50)+\mathrm{Mg}^{2+}(50)+\mathrm{Fe}^{2+}(50)$ & 1.0 & 1.0 & $100.0 \pm 0.0$ \\
\hline & & 50 & 49.95 & $99.6 \pm 1.0$ \\
\hline \multirow[t]{2}{*}{$\mathrm{E}$} & As in $\mathrm{D}+\mathrm{Ca}^{2+}(50)+\mathrm{Al}^{3+}(50)+\mathrm{W}^{\mathrm{VI}}(50)+\mathrm{Cd}^{2+}(50)+\mathrm{Ni}^{2+}(50)$ & 1.0 & 0.99 & $99.0 \pm 1.5$ \\
\hline & & 50 & 49.90 & $99.8 \pm 2.0$ \\
\hline \multirow[t]{2}{*}{$\mathrm{F}$} & As in $\mathrm{E}+\mathrm{Na}^{+}(50)+\mathrm{K}^{+}(50)+\mathrm{Zn}^{2+}(50)+\mathrm{Li}^{+}(50)+\mathrm{Ce}^{3+}(50)$ & 1.0 & 0.98 & $98.0 \pm 0.5$ \\
\hline & & 50 & 49.98 & $99.96 \pm 0.6$ \\
\hline
\end{tabular}

${ }^{a}$ Average of five analyses of each sample. ${ }^{b}$ The measure of precision is the standard deviation (SD). 
Table 5 Determination of cerium in some certified reference materials

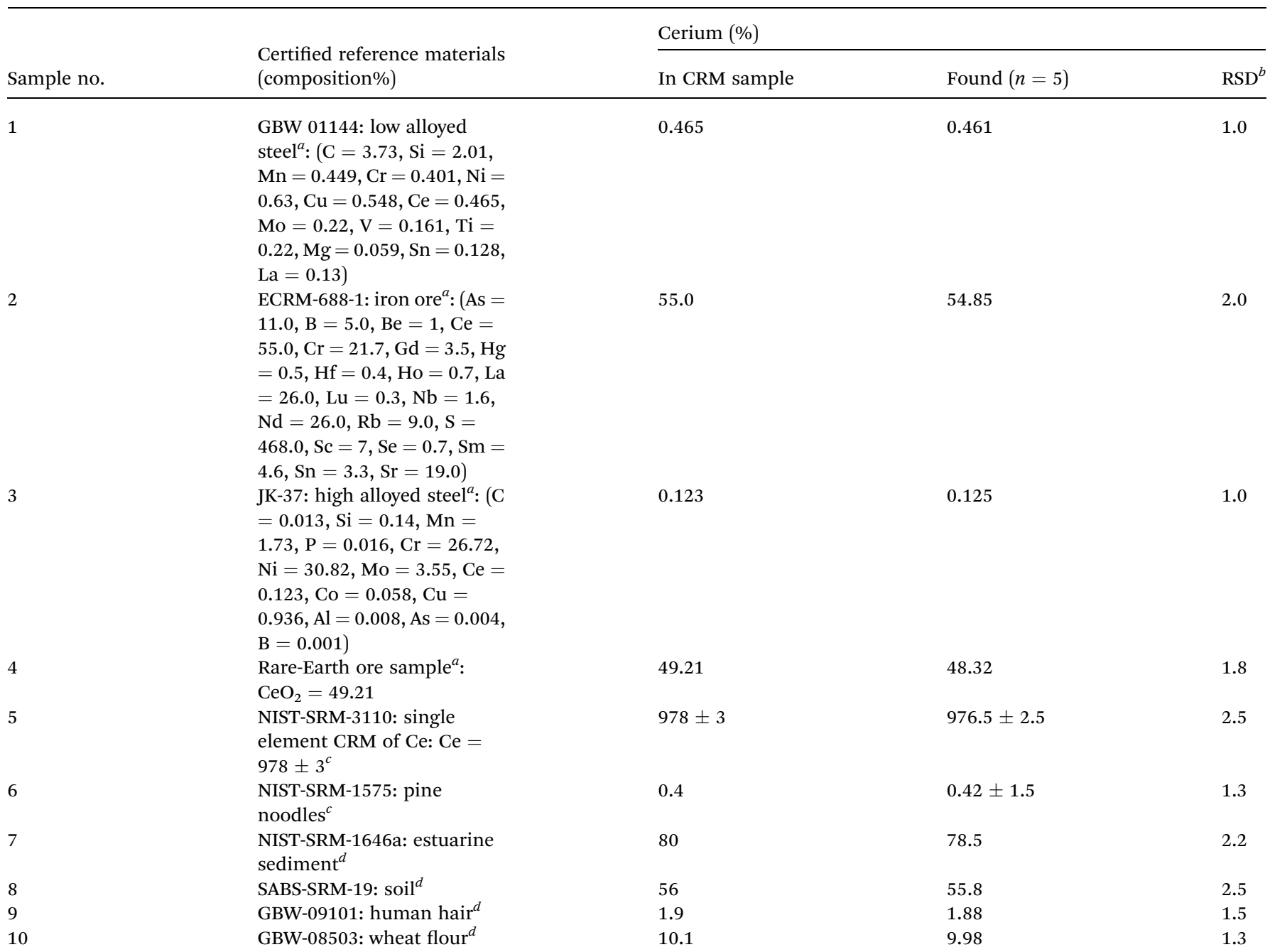

${ }^{a}$ The standard sample was obtained from The Baotou Institute of Rare Earth, Baotou, China. ${ }^{b}$ The measure of precision is the relative standard deviation (RSD). ${ }^{c}$ Values in $\mu \mathrm{g} \mathrm{g}^{-1}$. ${ }^{d}$ Values in $\mathrm{mg} \mathrm{kg}^{-1}$.

cerium(Iv) and the mixture was heated on a hot plate until white fumes of sulfur trioxide, following a method recommended by Greenberg et al. ${ }^{\mathbf{8 0}}$ The solution was cooled and neutralized with dilute $\mathrm{NH}_{4} \mathrm{OH}$ solution in presence of 1 $2 \mathrm{~mL}$ of $0.01 \%(\mathrm{w} / \mathrm{v})$ EDTA solution. Resulting solution was then filtered through a Whatman No. 40 filter paper and quantitatively transferred into a $25 \mathrm{~mL}$ calibrated flask and made up to the mark with de-ionized water. An aliquot (1-2 $\mathrm{mL}$ ) of this water sample was pipetted into a $10 \mathrm{~mL}$ calibrated flask and the cerium content was determined as described under the general procedure using tartrate or EDTA as masking agent. The results of analyses of environmental water samples from various sources for cerium are shown in Table 6.

Most spectrofluorimetric methods for determination of cerium in natural and sea-water require preconcentration or standard addition of cerium. ${ }^{\mathbf{8 1}}$ The concentration of cerium in natural and sea water is a few $\mathrm{ngL}^{-1}$ in developed countries. ${ }^{\mathbf{8 1}}$
Determination of cerium in biological samples. Human blood or milk (2-3 mL) or urine (10-20 mL) or hair (3-5 g) sample was taken into a $100 \mathrm{~mL}$ Micro-Kjeldahl flask. A glass bead and $10 \mathrm{~mL}$ of concentrated nitric acid were added, and the flask was placed on the digester under gentle heating. The sample was digested in the presence of an excess freshly prepared ammonium persulphate solution ( $2 \mathrm{~mL}$ of $2 \% \mathrm{w} / \mathrm{v}$ ) to oxidize cerium(III) to cerium(IV) according to the method recommended by Stahr. ${ }^{82}$ As the heating process continued $1 \mathrm{~mL}$ of $\mathrm{H}_{2} \mathrm{SO}_{4}$ is added and heated for about 0.5 hours to dense white fumes of sulphur trioxide. When the initial brisk reaction was completed, the solution was removed and cooled at room temperature and neutralized with dilute $\mathrm{NH}_{4} \mathrm{OH}$ solution in presence of 1-2 mL of $0.01 \%$ (w/v) EDTA solution. Resulting solution was then filtered through a Whatman No. 40 filter paper and quantitatively transferred into a $25 \mathrm{~mL}$ calibrated flask and made up to the mark with de-ionized water. A suitable aliquot (1-2 mL) of the final solution was pipetted out into 
Table 6 Determination of cerium in some environmental water samples

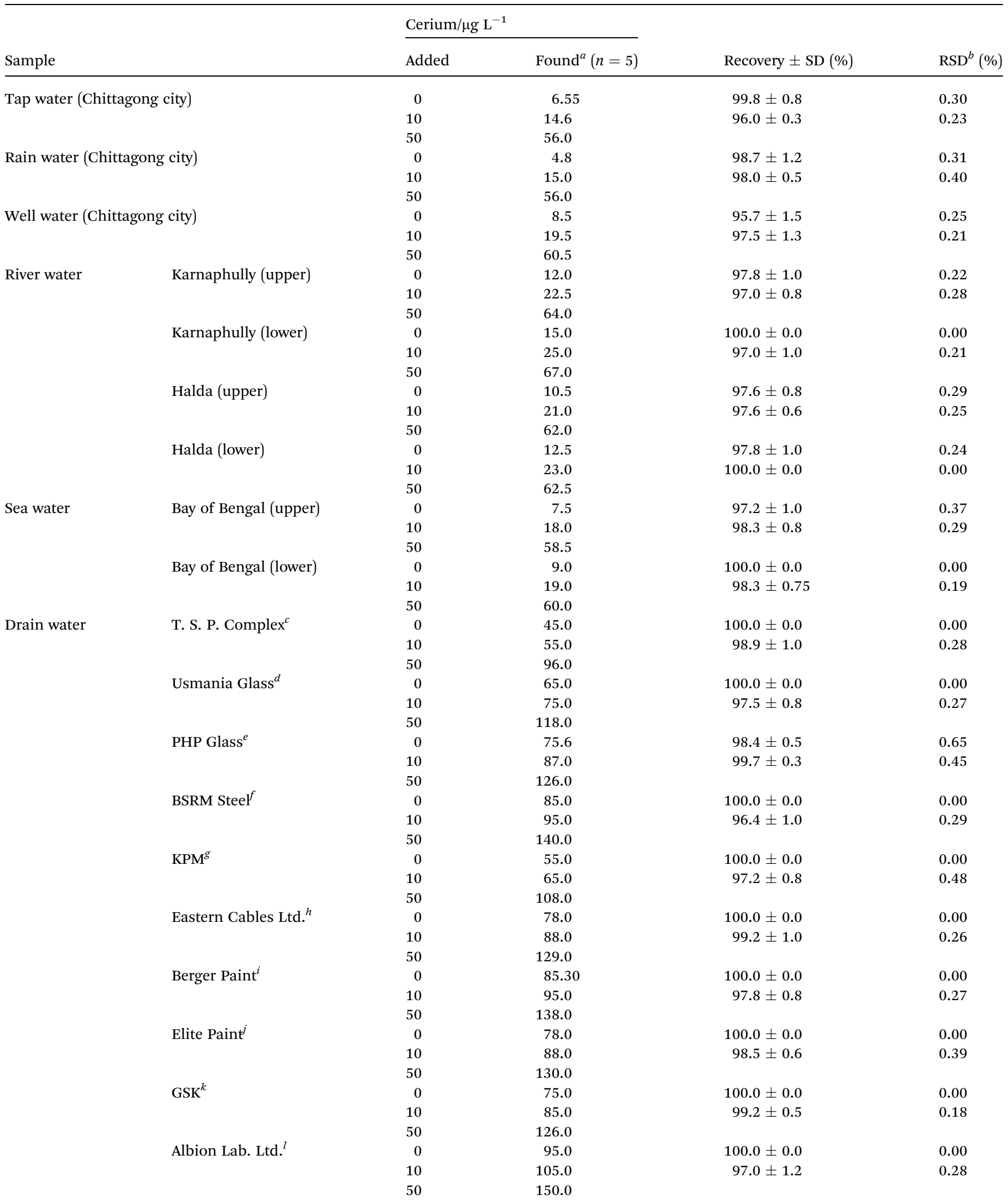

${ }^{a}$ Average of five replicate determinations of each sample. ${ }^{b}$ The measure precision is the relative standard deviation (RSD). ${ }^{c}$ T. S. P. Complex Ltd., Patenga, Chittagong. ${ }^{d}$ Usmania Glass Sheet Factory Ltd., Chandgaon, Chittagong. ${ }^{e}$ PHP Glass factory, Chittagong. ${ }^{f}$ Bangladesh Steel Re-rolling Mills Ltd. (BSRM), Baizid Bosthami, Chittagong. ${ }^{g}$ Karnaphuly Paper Mills, Chandraghona, Chittagong. ${ }^{h}$ Eastern Cables Ltd., Patenga, Chittagong. ${ }^{i}$ Berger Paints Bangladesh Limited, Kalurghat, Chittagong. ${ }^{j}$ Elite Paint \& Chemical Industries Ltd., Agrabad, Chittagong. ${ }^{k}$ Glaxo SmithKline Bangladesh Ltd., Fouzderhat, Chittagong. ${ }^{l}$ Albion Laboratories Ltd., Muradpur. 
Table 7 Determination of cerium in some human fluids and hair sample

\begin{tabular}{|c|c|c|c|c|c|c|}
\hline & \multirow[b]{2}{*}{ Sample source ${ }^{a}$} & \multirow[b]{2}{*}{ Sample } & \multicolumn{4}{|c|}{ Cerium/ng L ${ }^{-1}$} \\
\hline Serial no. & & & Found & $\operatorname{RSD}(\%)$ & Found & $\operatorname{RSD}(\%)$ \\
\hline \multirow[t]{2}{*}{1} & Brain disorder (male) & Blood & 343.5 & 2.0 & 345.8 & 2.5 \\
\hline & & Urine & 86.8 & 1.5 & 88.5 & 1.8 \\
\hline 2 & Liver cirrhosis patient (male) & Blood & 315.6 & 2.8 & 320.5 & 2.2 \\
\hline \multirow[t]{2}{*}{3} & Neurological problem (male) & Blood & 385.0 & 2.5 & 388.5 & 2.6 \\
\hline & & Urine & 73.0 & 1.6 & 75.8 & 1.5 \\
\hline \multirow[t]{2}{*}{4} & Kidney disease patient (male) & Blood & 205.6 & 2.0 & 210.8 & 1.8 \\
\hline & & Urine & 52.8 & 1.8 & 54.5 & 1.5 \\
\hline \multirow[t]{2}{*}{5} & Lung cancer patient (female) & Blood & 425.6 & 2.5 & 430.0 & 2.0 \\
\hline & & Urine & 168.5 & 1.8 & 110.8 & 1.7 \\
\hline 8 & & Urine & 55.8 & 1.8 & 58.5 & 2.0 \\
\hline 9 & Bangladeshi lactating mother & Milk & 58.8 & 1.2 & 58.6 & 1.5 \\
\hline 10 & Normal human hair (female) & Human hair $^{b}$ & 2.3 & 1.5 & 2.5 & 1.6 \\
\hline
\end{tabular}

a $10 \mathrm{~mL}$ calibrated flask and the cerium content was determined as described under the general procedure using EDTA or tartrate as masking agent. The results of biological analyses by the spectrofluorimetric method were found to be in excellent agreement with those obtained by ICP-OES. The results are shown in Table 7. The abnormally high values for the human lung cancer patient are probably due to the toxicity of cerium oxide nano-particles in human lung cancer cells. ${ }^{83}$ The occurrences of such high cerium content are also reported in lung cancer patient from some developed countries. ${ }^{83}$

Determination of cerium in some surface soil samples. An air-dried homogenized soil sample $(10 \mathrm{~g})$ was accurately weighed and placed in a $100 \mathrm{~mL}$ Micro-Kjeldahl flask. The sample was digested in the presence of an excess oxidizing agent $(2 \mathrm{~mL}$ of $2 \%$ freshly prepared ammonium persulfate solution) to oxidize cerium(III) to cerium(Iv) following method recommended by Jackson.$^{84}$ As the heating process continued $1 \mathrm{~mL}$ of $\mathrm{H}_{2} \mathrm{SO}_{4}$ is added and heated for about 5 minutes to dense white fumes of sulphur trioxide. The solution was then cooled at room temperature and neutralized with dilute $\mathrm{NH}_{4} \mathrm{OH}$ solution in presence of $1-2 \mathrm{~mL}$ of $0.01 \%(\mathrm{w} / \mathrm{v})$ EDTA solution. The content of the flask was then filtered through a Whatman No. 40 filter paper and quantitatively transferred into a $25 \mathrm{~mL}$ calibrated flask and made up to the mark with de-ionized water. A suitable aliquot (1-2 mL) of the final solution was pipetted out into a $10 \mathrm{~mL}$ calibrated flask and the cerium content was determined as described under the general procedure using tartrate or EDTA as masking agent. The cerium content was then determined by the above procedure and quantified from a calibration graph prepared concurrently. The average value of

Table 8 Determination of cerium in some surface soil samples

\begin{tabular}{|c|c|c|c|}
\hline Serial no. & Sample source ${ }^{c}$ & Cerium $\left(\mathrm{mg} \mathrm{kg}^{-1}\right)^{a}(n=5)$ & $\operatorname{RSD}^{b}(\%)$ \\
\hline $\mathrm{S}_{1}$ & Fertilizer industrial soil (T. S. P. Complex, Chittagong) & 51.8 & 1.2 \\
\hline $\mathrm{S}_{2}{ }^{c}$ & Glass industrial soil (PHP Glass) & 63.5 & 1.5 \\
\hline $\mathrm{S}_{4}$ & Paint industry soil (Berger Paint) & 85.8 & 1.6 \\
\hline $\mathrm{S}_{5}$ & Paint industry soil (Elite Paint) & 77.5 & 1.5 \\
\hline $\mathrm{S}_{6}$ & Industrial soil (Eastern Cables Ltd) & 75.2 & 1.8 \\
\hline $\mathrm{S}_{9}$ & Road side soil (Chittagong to Dhaka) & 75.0 & 1.9 \\
\hline $\mathrm{S}_{10}$ & Pharmaceutical soil (GlaxoSmithKline) & 135.8 & 1.8 \\
\hline
\end{tabular}

${ }^{a}$ Average of five analyses of each sample. ${ }^{b}$ The measure of precision is the relative standard deviation (RSD). ${ }^{c}$ Composition of the soil samples: C, N, P, K, Na, Ca, Mg, Ce, $\mathrm{Cu}, \mathrm{Mo}, \mathrm{Fe}, \mathrm{Pb}, \mathrm{V}, \mathrm{Zn}, \mathrm{Mn}, \mathrm{Co}, \mathrm{NO}_{3}, \mathrm{SO}_{4}$ et al. 
Table 9 Determination of cerium in some bone samples

\begin{tabular}{|c|c|c|c|c|}
\hline Serial no. & Bone sample & Cerium $\left.(\mu \mathrm{g} \mathrm{kg})^{-1}\right)^{a}(n=5)$ & $\operatorname{RSD}^{b}(\%)$ & Sample source \\
\hline 1 & Human (adult) & 510.5 & 1.5 & Chittagong Medical College Hospital, Chittagong \\
\hline 2 & Human (baby) & 495.6 & 1.0 & Chittagong Medical College Hospital, Chittagong \\
\hline 4 & Bull & 321.8 & 2.0 & Local market, Chittagong \\
\hline 5 & Hen (deshi) & 125.8 & 1.8 & Local market, Chittagong \\
\hline 6 & Cock (deshi) & 130.5 & 1.6 & Local market, Chittagong \\
\hline 9 & Sheep & 465.8 & 1.9 & Local market, Chittagong \\
\hline 10 & Buffalo & 498.5 & 2.5 & Local market, Chittagong \\
\hline
\end{tabular}

cerium in the Chittagong region surface soil was found to be $73.25 \mathrm{mg} \mathrm{kg}^{-1}$. The results are shown in Table 8 .

Determination of cerium in bone samples. An air-dried, finely crushed and homogenized bone sample $(1.0 \mathrm{~g})$ was accurately weighed and placed in a $100 \mathrm{~mL}$ Micro-Kjeldahl flask. The sample was digested in the presence of an excess oxidizing agent $(2 \mathrm{~mL}$ of $2 \%$ freshly prepared ammonium persulphate solution) to oxidize cerium(III) to cerium(Iv) following method recommended by Stahr. ${ }^{82}$ As the heating process continued $1 \mathrm{~mL}$ of $\mathrm{H}_{2} \mathrm{SO}_{4}$ is added and heated for about 0.5 hours to dense white fumes of sulphur trioxide. The solution was then cooled at room temperature and neutralized with dilute $\mathrm{NH}_{4} \mathrm{OH}$ solution in presence of $1-2 \mathrm{~mL}$ of $0.01 \%$ (w/v) EDTA solution. Resulting solution was then filtered through a Whatman No. 40 filter paper and quantitatively transferred into a $25 \mathrm{~mL}$ calibrated flask and made up to the mark with de-ionized water.

A suitable aliquot (1-2 mL) of the final solution was pipetted out into a $10 \mathrm{~mL}$ calibrated flask and the cerium content was determined as described under the general procedure using tartrate or EDTA as masking agent. The cerium content was then determined by the above procedure and quantified from a calibration graph prepared concurrently. The results are shown in Table 9.

Determination of cerium in some vegetable, food and fruit samples. The vegetable and fruit samples collected prior to the determination were pretreated in the following way: edible portion of samples was first washed clean with tap water followed by rewashing with de-ionized water. After removing deionized water from the surface of vegetables and fruits, the samples were cut into small pieces and dried at $65^{\circ} \mathrm{C}$ in oven. An air vegetables and fruits samples (10 g) were ground in a mortar and taken in a $100 \mathrm{~mL}$ Micro-Kjeldahl flask in presence of excess oxidizing agent and digested following a method recommended by $S$ tahr $^{82}$ and $10 \mathrm{~mL}$ of concentrated nitric acid were added and the flask was placed on the digester under gentle heating. When the initial brisk reaction was over, the solution was removed and cooled at room temperature. $1 \mathrm{~mL}$ volume of concentrated sulfuric acid was added carefully, followed by the addition of $2 \mathrm{~mL}$ of concentrated $\mathrm{HF}$, and heating was continued for at least $\frac{1}{2} \mathrm{hr}$ and then cooled. In the resulting solution $2 \mathrm{~mL}$ of $2 \%(\mathrm{w} / \mathrm{v})$ of freshly prepared ammonium persulphate is added. The mixture of each foodstuff was heated

Table 10 Determination of cerium in some food, fruit and vegetable samples

\begin{tabular}{|c|c|c|c|c|c|c|}
\hline \multirow[b]{3}{*}{ Serial no. } & \multirow[b]{3}{*}{ Sample } & \multicolumn{4}{|c|}{ Cerium $/ \mathrm{mg} \mathrm{kg}^{-1}$, found $^{a} \pm \mathrm{SD}(n=5)$} & \multirow[b]{3}{*}{ Sample source } \\
\hline & & \multicolumn{2}{|c|}{ ICP-OES $(n=5)$} & \multicolumn{2}{|c|}{$\begin{array}{l}\text { Proposed method } \\
(n=5)\end{array}$} & \\
\hline & & Found & $\mathrm{RSD}^{b}$ & Found & $\mathrm{RSD}^{b}$ & \\
\hline 1 & Carrot (Daucus carota) & 20.5 & 1.8 & 21.8 & 2.0 & Local market, Chittagong \\
\hline 4 & Mango (Mangifera indica) & 15.6 & 2.0 & 16.8 & 2.1 & Local market, Rajshahi \\
\hline 5 & Rice (Oryza sativa) & 9.9 & 1.8 & 10.1 & 2.0 & Local market, Chittagong \\
\hline 6 & Arum (Arum discorides) & 14.9 & 1.8 & 15.5 & 2.0 & Local market, Chittagong \\
\hline 7 & Radish (Raphanus sativus) & 10.5 & 1.7 & 10.9 & 1.8 & Local market, Chittagong \\
\hline 8 & Potato (Solanum tuberosum) & 10.8 & 1.5 & 11.5 & 1.8 & Local market, Chittagong \\
\hline 9 & Spinach (Spinacia oleracea) & 8.5 & 1.2 & 9.8 & 1.5 & Local market, Chittagong \\
\hline
\end{tabular}

${ }^{a}$ Average of five replicate analyses of each sample. ${ }^{b}$ The measure of precision is the relative standard deviation (RSD). 
Table 11 Determination of cerium(III) and cerium(Iv) speciation in mixtures

\begin{tabular}{|c|c|c|c|c|c|c|c|}
\hline \multirow[b]{2}{*}{ Serial no. } & \multirow{2}{*}{$\begin{array}{l}\mathrm{Ce}(\mathrm{IV}): \\
\mathrm{Ce}(\mathrm{III})\end{array}$} & \multicolumn{2}{|c|}{$\begin{array}{l}\text { Ce, taken } \\
\left(\mu \mathrm{g} \mathrm{L}^{-1}\right)\end{array}$} & \multicolumn{2}{|c|}{$\begin{array}{l}\text { Ce, found } \\
\left(\mu g L^{-1}\right)\end{array}$} & \multicolumn{2}{|c|}{ Error $\left(\mu \mathrm{g} \mathrm{L} \mathrm{L}^{-1}\right)$} \\
\hline & & $\mathrm{Ce}(\mathrm{Iv})$ & $\mathrm{Ce}($ III) & Ce(Iv) & $\mathrm{Ce}(\mathrm{III})$ & $\mathrm{Ce}(\mathrm{Iv})$ & $\mathrm{Ce}(\mathrm{III})$ \\
\hline 1 & $1: 1$ & 10 & 10 & 9.99 & 9.98 & 0.01 & 0.02 \\
\hline 1 & $1: 1$ & 10 & 10 & 1.00 & 1.00 & 0.00 & 0.00 \\
\hline 1 & $1: 1$ & 10 & 10 & 9.98 & 9.99 & 0.02 & 0.01 \\
\hline
\end{tabular}

Mean error: $\mathrm{Ce}(\mathrm{Iv})= \pm 0.01, \mathrm{Ce}(\mathrm{III})= \pm 0.01$

Standard deviation: $\mathrm{Ce}(\mathrm{IV})= \pm 0.005, \mathrm{Ce}(\mathrm{III})= \pm 0.006$

$\begin{array}{llllllll}1 & 1: 5 & 10 & 50 & 9.99 & 49.98 & 0.01 & 0.02 \\ 1 & 1: 5 & 10 & 50 & 9.98 & 49.99 & 0.02 & 0.01 \\ 1 & 1: 5 & 10 & 50 & 9.99 & 49.98 & 0.01 & 0.02\end{array}$

Mean error: $\mathrm{Ce}(\mathrm{Iv})= \pm 0.013, \mathrm{Ce}(\mathrm{III})= \pm 0.016$

Standard deviation: $\mathrm{Ce}(\mathrm{Iv})= \pm 0.0058, \mathrm{Ce}(\mathrm{III})= \pm 0.006$

$\begin{array}{rrrrrrrr}1 & 1: 10 & 10 & 100 & 9.98 & 99.99 & 0.02 & 0.01 \\ 1 & 1: 10 & 10 & 100 & 10.00 & 100.00 & 0.00 & 0.00 \\ 1 & 1: 10 & 10 & 100 & 9.99 & 99.98 & 0.01 & 0.02\end{array}$

Mean error: $\mathrm{Ce}(\mathrm{IV})= \pm 0.01, \mathrm{Ce}(\mathrm{III})= \pm 0.01$

Standard deviation: $\mathrm{Ce}(\mathrm{Iv})= \pm 0.005, \mathrm{Ce}(\mathrm{III})= \pm 0.006$

below the boiling point for 5-10 min to oxidize cerium(III) to cerium(Iv). The solutions were then cooled and neutralized with dilute $\mathrm{NH}_{4} \mathrm{OH}$ in presence of $1-2 \mathrm{~mL}$ of $0.01 \%(\mathrm{w} / \mathrm{v})$ EDTA solution. The resulting solution was filtered through a Whatman No. 40 filter paper and quantitatively transferred into a $25 \mathrm{~mL}$ calibrated flask and mixed well and made up to the mark with de-ionized water.
The food samples used were rice, wheat and corn and these were used under dry conditions. Each sample was first ground in a mortar. Corn and fruit samples ( $2 \mathrm{~g}$ ) or rice and wheat samples $(1 \mathrm{~g})$ were weighed accurately and placed in a porcelain crucible and charred in an electric furnace; the sample was ashen at $555{ }^{\circ} \mathrm{C}$ in a muffle furnace in presence of excess oxidizing agent following a method recommended by Mitra. ${ }^{78}$ To it, $2.0 \mathrm{~mL}$ of $\mathrm{HCl}$ and $10 \mathrm{~mL}$ of water were added to the ash. The mixture of each foodstuff was heated with $2 \mathrm{~mL}$ of $2 \%(\mathrm{w} / \mathrm{v})$ freshly prepared ammonium persulphate below the boiling point for 5-10 min below the boiling point to complete oxidation from $\mathrm{Ce}(\mathrm{III})$ to $\mathrm{Ce}(\mathrm{Iv})$. The solutions were cooled and neutralized with dilute $\mathrm{NH}_{4} \mathrm{OH}$ in presence of $1-2 \mathrm{~mL}$ of $0.01 \%$ (w/v) EDTA solution and filtered. The resulting solution was quantitatively transferred into a $25 \mathrm{~mL}$ calibrated flask and mixed well and made up to the mark with de-ionized water.

A suitable aliquot (1-2 mL) of the final digested solution was pipetted into a $10 \mathrm{~mL}$ calibrated flask and the cerium content was determined as described under the general procedure using tartrate as masking agent. High value of cerium for Daucus carota (carrot) is probably due to the involvement of high cerium concentration in the soil. The results of food and vegetables analyses by spectrofluorimetric method were also found to be in excellent agreement with those obtained by ICP-OES. The results are shown in Table 10.

Determination of cerium(III) and cerium(Iv) speciation in mixtures. Suitable aliquots (1-2 mL) of cerium(IV + III) mixtures (preferably $1: 1,1: 5,1: 10$ ) were taken in a $25 \mathrm{~mL}$ Pyrex conical flask. A few drops (2-3 drops) of $2 \mathrm{M} \mathrm{H}_{2} \mathrm{SO}_{4}$, and $2-4 \mathrm{~mL}$ of $2 \%$

Table 12 Statistical comparison between proposed method with existing reported methods

\begin{tabular}{|c|c|c|c|c|c|}
\hline \multirow[b]{2}{*}{ Samples } & \multicolumn{5}{|l|}{$F$-test results ${ }^{a}$} \\
\hline & $\left(\mathrm{SD}_{1}^{2} / \mathrm{SD}_{2}^{2}\right)^{43}$ & $\left(\mathrm{SD}_{1}^{2} / \mathrm{SD}_{3}^{2}\right)^{48}$ & $\left(\mathrm{SD}_{1}^{2} / \mathrm{SD}_{4}^{2}\right)^{56}$ & $\left(\mathrm{SD}_{1}^{2} / \mathrm{SD}_{5}{ }^{2}\right)^{62}$ & $\left(\mathrm{SD}_{1}{ }^{2} / \mathrm{SD}_{6}{ }^{2}\right)^{67}$ \\
\hline Water & 0.107 & & 0.47 & 0.17 & 0.0011 \\
\hline Water & 0.0416 & & 0.091 & 0.023 & 0.55 \\
\hline Water & 0.259 & & 0.200 & 0.153 & \\
\hline Water & 0.819 & & & & \\
\hline Blood & 0.75 & & & & \\
\hline Blood & 0.65 & & & & \\
\hline Blood & 0.93 & & & & \\
\hline Soil & & 0.22 & 0.0004 & 0.0005 & \\
\hline Soil & & 0.89 & 0.0003 & 0.0004 & \\
\hline Soil & & 0.90 & 0.0009 & 0.0007 & \\
\hline Alloy & & 0.72 & & & \\
\hline Alloy & & 0.09 & & & \\
\hline Synthetic mixture & & 0.21 & & & \\
\hline Synthetic mixture & & 0.69 & & & \\
\hline Synthetic mixture & & 0.67 & & & \\
\hline Food & & & 0.68 & & \\
\hline Food & & & 0.72 & & \\
\hline Urine & & & & 1.02 & \\
\hline Urine & & & & 0.84 & \\
\hline Bone & & & & & 0.86 \\
\hline Wheat & & & & & 0.78 \\
\hline
\end{tabular}

${ }^{a}$ Tabulated $F$-value for $(5,5)$ degrees of freedom at $P(0.96)$ is $5.52 . \mathrm{SD}_{1}=$ standard deviation of proposed method, $\mathrm{SD}_{2}=$ standard deviation of reference method, ${ }^{43} \mathrm{SD}_{3}=$ standard deviation of reference method, ${ }^{48} \mathrm{SD}_{4}=$ standard deviation of reference method, ${ }^{56} \mathrm{SD}_{5}=$ standard deviation $^{6}$ of reference method, ${ }^{62} \mathrm{SD}_{6}=$ standard deviation of reference method. ${ }^{67}$ 


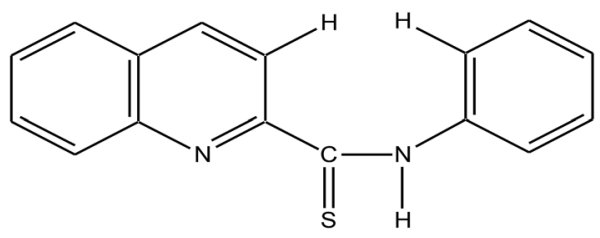

2-( $\alpha$-pyridyl)-thioquinaldinamide (PTQA)

Cyclization

$[\mathrm{H}+]$<smiles>Sc1nc2ncccc2c2cc3ccccc3nc12</smiles>

(A)<smiles>S=c1[nH]c2ncccc2c2cc3ccccc3nc12</smiles>

(B)

Fig. 8 Mechanism of oxidative cyclization reaction of 2-( $\alpha$-pyridyl)-thioquinaldinamide (PTQA).

$(\mathrm{w} / \mathrm{v})$ freshly prepared ammonium persulphate were added to oxidize trivalent cerium to tetravalent cerium and the mixture was heated gently with further addition of $5 \mathrm{~mL}$ water, if necessary, for 5 minutes to drive off the excess persulphate, then the mixture was cooled to room temperature. The reaction mixture was then cooled and neutralized with dilute $\mathrm{NH}_{4} \mathrm{OH}$ in presence of $1-2 \mathrm{~mL}$ of $0.01 \%(\mathrm{w} / \mathrm{v})$ EDTA solution. The solution was transferred quantitatively into a $10 \mathrm{~mL}$ volumetric flask and $1 \mathrm{~mL}$ of $9.8 \times 10^{-4} \mathrm{M}$ PTQA reagent solution was added followed by the addition of $1 \mathrm{~mL}$ of $0.001 \mathrm{M} \mathrm{H}_{2} \mathrm{SO}_{4}$. It was made up to the mark with de-ionized water. The fluorescence intensity was measured then being cooled at room temperature, $(25 \pm$ 5) ${ }^{\circ} \mathrm{C}$, at $370 \mathrm{~nm}$ when excited at $303 \mathrm{~nm}$, against a reagent blank. The total cerium content was calculated with the help of a calibration graph prepared concurrently.

An equal aliquot (1-2 mL) of the above cerium(IV + III) mixture was taken into a $25 \mathrm{~mL}$ conical flask. The solution was neutralized with dilute $\mathrm{NH}_{4} \mathrm{OH}$ in presence of $1-2 \mathrm{~mL}$ of $0.01 \%(\mathrm{w} / \mathrm{v})$ EDTA solution. After, the content of the beaker was transferred quantitatively into a $10 \mathrm{~mL}$ volumetric flask, $1 \mathrm{~mL}$ of $9.8 \times 10^{-3} \mathrm{M}$ PTQA reagent solution was added, followed by the addition of $1 \mathrm{~mL}$ of $0.001 \mathrm{M} \mathrm{H}_{2} \mathrm{SO}_{4}$. It was made up to the mark with de-ionized water. After $5 \mathrm{~min}$ the fluorescence intensity was measured following the general procedure at $370 \mathrm{~nm}$ when excited at $303 \mathrm{~nm}$ against a reagent blank, as before. The cerium concentration was calculated in $\mu \mathrm{g} \mathrm{L}^{-1}$ or $n g \mathrm{~L}^{-1}$ with the aid of a calibration graph. This gives a measure of cerium(rv) originally present in the mixture. This value was subtracted from that of the total cerium to determine the cerium(III) present in the mixture. The results of the assessment of speciation of $\mathrm{Ce}(\mathrm{VI})$ and $\mathrm{Ce}(\mathrm{III})$ were found to be highly reproducible. The occurrence of such reproducible results is also reported for different oxidation states of cerium. ${ }^{85}$ The results of a set of determination are given in Table 11.
The present method was compared with some reported

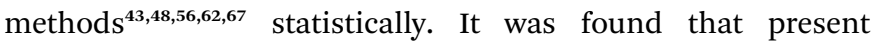
method is much superior those of the reported methods. The results are shown in Table 12.

\section{Conclusions}

A new rapid, ultra sensitive, highly selective and inexpensive spectrofluorimetric method with the cerium-PTQA system was developed for the determination of cerium in some real, environmental, biological, bone, food, and soil samples, for continuous monitoring to establish the pico-trace levels of cerium in different samples matrices. Compared with other methods, the proposed method has several remarkable analytical characteristics: firstly, the proposed method is highly sensitive that the amount, in $\mathrm{ng} \mathrm{L}^{-1}$, of cerium can be determined without preconcentration in diluted biological solutions. Secondly, the low detection limit, $0.1 \mathrm{ng} \mathrm{L}^{-1}$ i.e. $\mathrm{pg} \mathrm{g}^{-1}\left(10^{-12} \mathrm{pg}\right.$ $\mathrm{g}^{-1}$ ) levels can be measured without preconcentration or standard addition method. The proposed method is very simple, rapid, and stable. The reaction of cerium with PTQA is instantaneous, so it does not involve any stringent reaction conditions and offer the advantages of high stability of fluorescence intensity (over $24 \mathrm{~h}$ ) at room temperature, reliable and reproducible. Thirdly, the method has added the advantages of determining individual amounts of cerium(III) and cerium(Iv). With suitable masking agents, the reaction can be made highly selective and better reproducibility has been achieved (RSD $=0-$ $2 \%)$.

Finally, the proposed method using PTQA in aqueous solutions not only is one of the most sensitive methods for the determination of cerium but also is excellent in terms of selectivity, simplicity and precision (RSD: $0-2 \%$ ). Therefore, this 
method can be successfully used in routine analysis of picotrace amounts of cerium in real, environmental, biological, bone, food, vegetables and soil samples. It is a new method needs neither heating nor extraction to organic phase, works satisfactorily and could be an alternative method for the rapid determination of cerium in a wide variety of sample matricesand found superior to existing spectrofluorimetric methods reported in different literature.

\section{Conflicts of interest}

There are no conflicts to declare.

\section{References}

1 F. Riccardo, and S. Adriana, Intermetallic Chemistry, 2010, vol. 13 , pp. 370-389.

2 T. A. Ali, G. G. Mohamed, E. M. S. Azzam and A. A. Abd-elaal, Sens. Actuators, B, 2013, 191, 192.

3 A. Afkhami, T. Madrakian, A. Shirzadmehr, M. Tabatabaee and H. Bagheri, Sens. Actuators, B, 2012, 174, 237-248.

4 M. R. Awual, T. Yaita and H. Shiwaku, Chem. Eng. J., 2013, 228, 327-335.

5 A. Kumar, S. Babu, A. S. Karakoti, A. Schulte and S. Seal, Langmuir, 2009, 25, 10998-11009.

6 E. Diatloffa, F. W. Smith and C. J. Asher, J. Plant Nutr., 2008, 18, 1995-2009.

7 P. C. C. Faria, J. J. M. Orfao and M. F. R. Pereira, Appl. Catal., $B, 2009,88,341-350$.

8 T. Alessandro, C. deLeitenburg, B. Marta and D. Giuliano, Catal. Today, 1999, 50, 353-363.

9 C. L. Melcher and J. S. Schweitzer, IEEE Trans. Nucl. Sci., 1992, 39, 502-513.

10 I. Woo and K. Nishimoto, Met. Mater. Int., 2001, 7, 241-249.

11 A. N. Shmyreva, A. V. Borisov and N. V. Maksimchuk, Nanotechnol. Russ., 2010, 5, 382-391.

12 I. Celardo, E. Traversa and L. Ghibelli, J. Exp. Ther. Oncol., 2010, 9, 47-51.

13 S. Robert, H. J. Stevens and J. R. Varner, J. Non-Cryst. Solids, 1999, 249, 123-134.

14 R. Le Toquin and A. K. Cheetham, Chem. Phys. Lett., 2006, 423, 352.

15 A. Corma, P. Atienzar, H. Garcia and J. Y. Chane-Ching, Nat. Mater., 2004, 3, 394403.

16 E. P. Murray, T. Tsai and S. A. Barnett, Nature, 1999, 400, 649-658.

17 X. Feng, Y. S. Her, W. L. Zhang, J. Davis, E. Oswald, J. Lu, V. Bryg, S. Freeman and D. Gnizak, Mater. Res. Soc. Symp. Proc., 2003, 763, 173-181.

18 M. Ozawa, M. Kimura and A. Isogai, J. Alloys Compd., 1993, 193, 73-86.

19 K. H. Al-Sowdani and A. Townshend, Anal. Chim. Acta, 1986, 179, 469-476.

20 Y. Watanabe, V. Kain, T. Tonozuka, T. Shoji, T. Kondo and F. Masuyama, Scr. Mater., 2000, 42, 307-316.

21 E. K. Robert, The History and Use of Our Earth's Chemical Elements: A Reference Guide, 2006, p. 279.
22 L. Wang, Y. Yu, X. Huang, Z. Long and D. Cui, Chem. Eng. J., 2013, 215, 162-172.

23 S. Abhilash, M. K. Sinha and B. D. P. Sinha, Int. J. Miner. Process., 2014, 127, 70-81.

24 S. Hirano and K. T. Suzuki, Environ. Health Perspect., 1996, 104, 85-105.

25 D. I. Bleiwas, Potential for Recovery of Cerium Contained in Automotive Catalytic Converters, U.S. Department of the Interior: U.S. Geological Survey, 2013.

26 R. J. Lewis, Hazardous Chemicals Desk Reference, John Wiley \& Sons, 6th edn, 2008, pp. 300-337.

27 https:/www.webelements.com/cerium/chemistry.html, accessed January 2019.

28 http://weppi.gtk.fi/publ/foregsatlas/text/Ce.pdf, accessed July 2004.

29 M. A. Jakupec, P. Unfried and B. K. Keppler, Rev. Physiol., Biochem. Pharmacol., 2005, 153, 104-117.

30 P. Cukor and R. . P. Weberling, Anal. Chim. Acta, 1968, 41, 404-411.

31 A. N. Masiand and R. A. Olsina, Talanta, 1993, 40, 931-944. 32 M. Achilli, G. Ciceri, R. Ferraroli, D. Helati and W. Martinotti, Analyst, 1989, 114, 319-327.

33 V. K. Jain, A. Handa, S. S. Sait, P. Shrivastav and Y. K. Agrawal, Anal. Chim. Acta, 2001, 429, 237-243.

34 F. Shemirani and S. Reza Yousefi, Microchim. Acta, 2007, 153, 223-229.

35 B. Li, Y. Zhang and M. Yin, Analyst, 1997, 122, 543-549.

36 B. Li, Y. Sun and M. Yin, J. Anal. At. Spectrom., 1999, 14, 18431851.

37 H. L. Greenhaust, M. Feibush and L. Gordon, Anal. Chem., 1957, 29, 1531-1538.

38 L. Gordon and A. M. Feibush, Anal. Chem., 1955, 27, 10511062.

39 P. L. Sharma and L. H. Dieter, Talanta, 1966, 13, 347-356.

40 J. Wang, P. Farias and J. S. Mahmoud, Anal. Chim. Acta, 1985, 171, 215-221.

41 S. B. Khooand and J. Zhu, Electroanalysis, 1999, 11, 546-552. 42 J. G. Sen Gupta, Talanta, 1984, 31, 1053-1560.

43 T. I. Ivkova, R. P. Pantaler and Y. A. Povrozin, Anal. Chem. Lett., 2012, 2, 220-229.

44 A. Navas, F. S. Rojas and F. G. Sanchez, Mikrochim. Acta, 1982, 1, 175-184.

45 F. Grases, C. Genestarand and J. G. March, Microchem. J., 1984, 29, 237-249.

46 B. K. Pal, F. Toneguzzo and A. Corsini, Anal. Chim. Acta, 1977, 88, 353-365.

47 N. Jie, J. Yang and T. Liu, Talanta, 1994, 41, 415-423.

48 H. Tavallali and R. Nejabat, Asian J. Chem., 2009, 21, 24412449.

49 D. Ozyurt, B. Demirata and R. Apak, J. Fluoresc., 2011, 21, 2069-2077.

50 I. A. Darwish, A. S. Khedr, H. F. Askal and R. M. Mahmoud, Il Farmaco, 2005, 60, 555-563.

51 A. Akseli and Y. Rakicioğlu, Fresenius. J. Anal. Chem., 1996, 354, 424-431.

52 F. Salinas, C. Genestar and F. Grases, Microchem. J., 1982, 27, 32. 
53 K. H. Al-Sowdani and A. Townshend, Anal. Chim. Acta, 1986, 179, 469-477.

54 F. Zhao and W. Zhao, J. Fluoresc., 2012, 22, 529-536.

55 I. Berregi, D. J. Senén and C. J. Alfonso, Talanta, 1999, 48, 719-725.

56 J. X. Meng, H. J. Wu and D. X. Feng, Spectrochim. Acta, Part A, 2000, 56, 1925-1933.

57 M. M. Karim, S. H. Lee, Y. S. Kim, H. S. Bae and S. B. Hong, J. Fluoresc., 2006, 16, 17.

58 N. Jie, Z. Si, J. Yang, Q. Zhang, X. Huang and D. Yang, Mikrochim. Acta, 1997, 126, 93-99.

59 D. T. Burns, C. D. P. Dangolle and M. Harriott, Mikrochim. Acta, 1995, 119, 49-56.

60 Y. Rakicioğlu and A. Akseli, J. Fluoresc., 1998, 8, 1-8.

61 J. Nianqin, Y. Jinghe and G. Jian, Fenxi Huaxue, 1992, 20, 847-853.

62 A. Akseli and Y. Rakicioğlu, Talanta, 1996, 43, 1983-1998.

63 P. Cukor and R. P. Weberling, Anal. Chim. Acta, 1968, 41, 404-409.

64 Z. Holzbecher, Collect. Czech. Chem. Commun., 1989, 54, 616627.

65 C. Huang and X. Chi, J. Beijing Normal Univ. (Nat. Sci.), 1993, 03, 235-243.

66 Y. Takayama, T. Ujihara, K. Morishige, Y. Nishikawa and B. Kagaku, Bunseki Kagacu, 1986, 35, 713-719.

67 A. Feng, Q. Hu and W. Wang, J. Food Sci. Technol., 2011, 48(4), 489-494.

68 M. K. Rofouei, N. Tajarrod, M. Masteri-Farahani and R. Zadmard, J. Fluoresc., 2015, 25, 1855-1864.

69 H. D. Porter, J. Am. Chem. Soc., 1954, 76, 127-136.

70 M. Jamaluddin Ahmed, M. Tazul Islam and F. Hossain, RSC $A d v .$, 2018, 8, 5509-5522.
71 Vogel's Textbook of Quantitative Chemical Analysis, ed. G. H. Jeffery, J. Bassett, J. Mendham and R. C. Denney, ELBS, Bath Press Ltd., London, 5th edn, 1994, pp. 380-382.

72 A. K. Mukharjee, Analytical Chemistry of Zirconium and Hafnium, Pergamon Press, New York, 1st edn, 1970, p. 12.

73 B. K. Pal and B. Chowdhury, Mikrochim. Acta, 1984, 11, 121.

74 C. B. Ojeda, A. G. de Torres, F. S. Rojas and J. M. C. Pavon, Analyst, 1987, 112, 1499.

75 M. Jamaluddin Ahmed, C. D. Stalikas, P. G. Veltsistas, S. M. Tzouwara-Karayanni and M. I. Karayannis, Analyst, 1997, 122, 221-229.

76 B. K. Pal, M. Jamaluddin Ahmed and A. K. Chkraborty, Analyst, 1990, 115, 439-449.

77 B. K. Pal, A. K. Chkraborty and M. Jamaluddin Ahmed, Anal. Chim. Acta, 1988, 206, 351-355.

78 Sample Preparation Techniques in Analytical Chemistry, ed. S. Mitra, Wiley-Intersciences, New Jersey, 2003, pp. 125-133.

79 C. Sun, J. Y. Yang and S. R. Tzeng, Analyst, 1999, 124, 421429.

80 Standard Methods for the Examination of Water and Wastewater, ed. E. A. Greenberg, S. L. Clesceri and D. A. Eaton, American Public Health Association, Washington D. C., 18th edn, 1992, pp. 3-253.

81 P. Chambon, U. Lound and E. Ohanian, WHO Guidelines for Drinking Water Quality, Recommendations, WHO, Geneva, 2nd edn, 1993.

82 H. M. Stahr, Analytical Methods in Toxicology, John Wiley and Sons, New York, 3rd edn, 1991, p. 85.

83 S. Mittal and A. K. Pandey, BioMed Res. Int., 2014, 5, 126-136. 84 M. L. Jackson, Soil Chemical Analysis, Prentice Hall, Englewood Cliffs, 1965, p. 326.

85 https://www.ncbi.nlm.nih.gov/pubmed/24090406, accessed October 2013. 